\title{
Classifying compound coastal storm and heavy rainfall events in the north-western Spanish Mediterranean
}

\author{
Marc Sanuy ${ }^{1}$, Tomeu Rigo ${ }^{2}$, José A. Jiménez ${ }^{1}$, and M. Carmen Llasat ${ }^{3}$ \\ ${ }^{1}$ Laboratori d'Enginyeria Marítima, Universitat Politècnica de Catalunya, BarcelonaTech, c/Jordi Girona 1-3, \\ Campus Nord ed. D1, Barcelona 08034, Spain \\ ${ }^{2}$ Servei Meteorològic de Catalunya, C. Berlin, 38-46, Barcelona 08029, Spain \\ ${ }^{3}$ GAMA, Department of Applied Physics, University of Barcelona, Barcelona 08028, Spain
}

Correspondence: Marc Sanuy (marc.sanuy@upc.edu) and Jose A. Jiménez (jose.jimenez@upc.edu)

Received: 27 October 2020 - Discussion started: 1 December 2020

Revised: 6 April 2021 - Accepted: 26 May 2021 - Published: 1 July 2021

\begin{abstract}
The north-west (NW) Mediterranean coastal zone is a populous and well-developed area in which the impact of natural hazards like flash floods and coastal storms can result in frequent and significant damages. Although the occurrence and impacts of such hazards have been widely covered, few studies have considered their combined impact on the region, which would result in more damage. Within this context, this study analyses the occurrence and characteristics of compound extreme events of heavy rainfall episodes (as a proxy for flash floods) and coastal storms (using the maximum significant wave height) along the Catalan coast as a paradigm of the NW Mediterranean. Two different types of events are considered: multivariate, in which the two hazards occur at the same location, and spatially compounding, in which they occur within the same limited time window, and their impacts accumulate at distinct and separate locations. The analysis is regionally performed along a coastline extension of about $600 \mathrm{~km}$ by considering seven coastal sectors and their corresponding river catchment basins. Once the compound events are analysed, the synoptic atmospheric pressure fields are analysed to determine the prevailing weather conditions that generated them. Finally, a Bayesian network is used to fully characterize these events over the territory. The obtained results show that the NW Mediterranean, represented by the Catalan coast, has a high probability of experiencing compound extreme events. Despite the relatively small size of the study area, there are significant variations in the event characteristics along the territory, with the most frequent type being spatially compound, except in the northernmost sectors where multivariate events
\end{abstract}

dominate. These northern sectors also present the highest correlation in the intensity of both hazards. Three representative synoptic situations have been identified as dominant for the occurrence of these events, with different relative importance levels of the compounding drivers (rainfall and waves) and different distributions of impacts across coastal basins. Overall, results obtained from specific events indicated that heavy rainfall is related to the most significant impacts despite having a larger spatial reach.

\section{Introduction}

Coastal zones are one of the highest risk areas in the world given the concentration of natural hazards, people, and buildings along coastlines (e.g. Kron, 2013). Among the different hazards, flooding is currently the most frequent, dangerous, and costly (IPCC, 2012; Blöschl et al., 2020), and it is very likely to significantly increase under climate change (e.g. Hallegatte et al., 2013; IPCC, 2014; Alfieri et al., 2015; Blöschl et al., 2020). One of the intrinsic characteristics of flooding in coastal areas is that it can be induced by different climatic drivers such as storm surge, run-up, rainfall, and/or river flow, each of which may act individually but are often interconnected (Berghuijs et al., 2019). Moreover, when flooding is induced by marine drivers, such as storm surge and/or waves, impacting sedimentary coastlines, erosion also occurs simultaneously. Thus, although risk assessments in coastal zones usually consider the impact of sea hazards and climate drivers individually (e.g. Michaelides et al., 2018; 
Van Dongeren et al., 2018), they should instead be considered as the result of compounding events (Hao et al., 2018; Ward et al., 2018). In this sense, an increasing number of studies have stressed the importance of compound flooding in coastal zones at different geographical scales (Wahl et al., 2015; Wu et al., 2018; Bevacqua et al., 2019; Hendry et al., 2019), including their potential increase under the influence of climate change (Moftakhari et al., 2017; Bevacqua et al., 2019). When the importance of these types of events is considered across Europe, the Mediterranean coastline can be considered a hotspot. On the one hand, more than $50 \%$ of its population is concentrated in the coastal zone, increasing the risk to human life due to flooding (Vinet et al., 2019). On the other hand, the relative frequency of flash floods in the region is the highest in Europe (Gaume et al., 2016), and impacts related to climate and environmental changes are more severe relative to the global average, with temperatures already reaching $+1.5^{\circ} \mathrm{C}$ relative to pre-industrial times (Cramer et al., 2018). This combination also implies an increase in coastal-storm-induced damage over the last decades (e.g. Jiménez et al., 2012; Garnier et al., 2018). However, there are a limited number of studies assessing the combined effect of different hazard-inducing climate drivers (Hall et al., 2014). In the north-west (NW) Mediterranean, Ballesteros et al. (2018a) analysed and compared the risk of flooding in the central part of the Catalan coast due to flash floods, storm waves, and sea-level rise; they concluded that flash floods induce higher risks in comparison with marinerelated flooding, even though they are acting on a smaller spatial scale along the coastline. However, they did not consider these different drivers to jointly contribute to compound flooding. With respect to compound flooding, most of the existing analyses are part of very large-scale studies (e.g. Bevacqua et al., 2019; Paprotny et al., 2020), with few examples at smaller regional scales (Wahl et al., 2015; Wu et al., 2018; Hendry et al., 2019). Among them, Bevacqua et al. (2019) identified Mediterranean coasts as the European areas with the highest probability of compound flooding under present conditions. As is the case with most existing studies of compound flooding, they considered that storm surge and precipitation were climate drivers that would act simultaneously. When characterizing coastal compound flooding from a riskoriented perspective, the definition of the compound event itself and the choice of contributing climatic drivers are key aspects to be considered. Recently, Zscheischler et al. (2020) proposed a classification of compound events into four main types, which facilitates the analysis of the mechanisms driving the impact and thereby provides a framework for risk adaptation. Using this classification, this study considers and analyses two main types of events: multivariate and spatially compounding.

A multivariate compounding event refers to the cooccurrence of hazards from multiple climate drivers in the same geographical region. This is the most common type of event when analysing compound coastal flooding, as de- fined by the co-occurrence of a marine driver (usually storm surge) and a "terrestrial" one such as rainfall or river flow acting at the same site (e.g. Wahl et al., 2015; Hendry et al., 2019). Due to the characteristics of coastal storms in the NW Mediterranean, waves are considered the main marine driver controlling the floodwater volume to the hinterland, since the wave-induced run-up, $\mathrm{Ru}$, is much larger than the magnitude of the storm surge (e.g. Mendoza and Jiménez, 2009; Mendoza et al., 2011). Moreover, the use of storm waves as the marine driver also potentially indicates the importance of interconnected erosion hazards (in addition to flooding). On the other hand, due to the nature of flooding in the NW Mediterranean coastal zone, heavy rainfall episodes are considered the main terrestrial drivers (as a proxy for runoff), which lead to flash floods (Cortès et al., 2018; Gaume et al., 2016).

Spatially compounding events refer to co-occurring hazards from different climate drivers at distant locations within a limited time window. From a risk management standpoint, these events are very relevant because they may overwhelm the capability of emergency-response services since these have to respond to a large number of emergency situations throughout the region at the same time. In this study, these events are defined by the co-occurrence of the two abovementioned hazards, heavy rainfall and coastal storms, within a time window of $3 \mathrm{~d}$ along the Catalan coast (NW Mediterranean, Spain). This time interval is used in the area to identify independent episodes between consecutive events. Thus, a location under such an event will experience only heavy rainfall or a coastal storm that will accumulate with hazards happening simultaneously, or in rapid succession, in other parts of the territory.

To put this study in the context of risk management, this work will also illustrate the associated impact of selected compound events. In any case, the impact is likely the result of a combination of climatic and societal drivers, with the climate drivers controlling the magnitude of the hazards (analysed herein) and the societal drivers causing an increase or decrease in the associated impacts (e.g. Raymond et al., 2020). One of the problems in properly accounting for these impacts in large geographical areas is the difficulty in obtaining after-event local data across the entire territory. However, a way to identify remarkable events is by considering the significance of their associated impacts in qualitative terms by analysing after-event press coverage and/or insurance data. In the study area, this has been done previously by Llasat et al. (2009) and Cortès et al. (2018) for flash floods and by Jiménez et al. (2012) for coastal storms. This will also be the approach adopted to illustrate the impact of selected events herein.

Within this context, the main aim of this work is to characterize the occurrence of compound flooding events along the Catalan coast (representative of the NW Mediterranean). To this end, we investigated the dependency between coastal storms and intense rainfall for the two types of compound events previously introduced: multivariate events, in which 


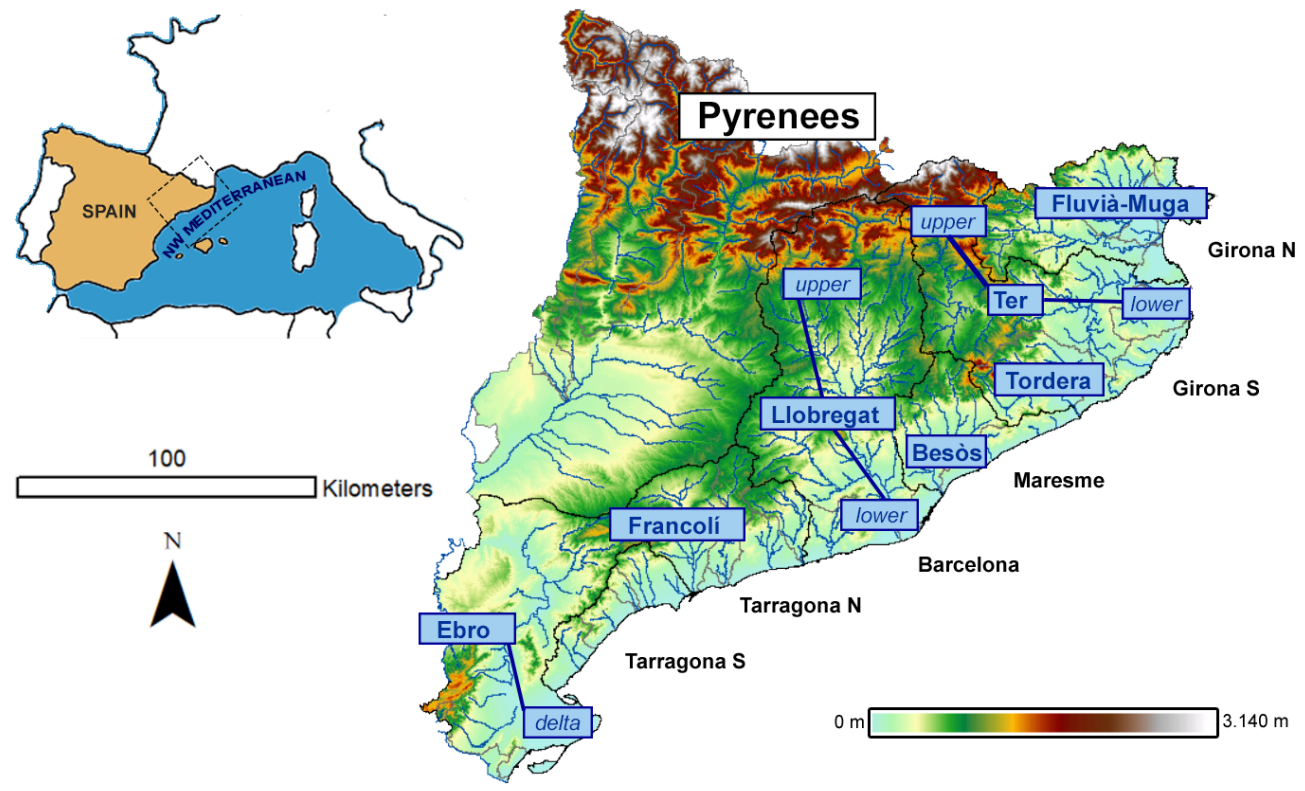

Figure 1. Study area and main coastal river systems. Digital elevation model $15 \mathrm{~m} \times 15 \mathrm{~m}$ by Institut Cartogràfic and Geològic de Catalunya (ICGC).

we search for the simultaneous presence (within a time range of $3 \mathrm{~d}$ ) of a coastal storm and a heavy rainfall episode in the same geographical area, and spatially compounding events, in which we search for the simultaneous presence (within a time range of $3 \mathrm{~d}$ ) of a coastal storm and a heavy rainfall episode in different geographical areas. Thus, (i) we quantify the occurrence frequency of the different types of compound events; (ii) we analyse the spatial variability of the different types of compound hazards and the dependence between extreme variables (rainfall and wave height); and (iii) we examine the prevailing synoptic meteorological patterns during the compound events to identify whether the meteorological drivers can be distinguished in terms of event type (multivariate vs. spatially compounding) and the intensity of the drivers. Finally, some examples of the identified events are outlined in terms of their characteristics and induced impacts.

The remainder of this paper is organized as follows. Section 2 introduces the study area and describes the data used. Section 3 presents the methodology used in the analysis. Section 4 presents the results of analysing compound events along the Catalan coast and illustrates them with selected remarkable events occurring in the study area during the last 30 years. Section 5 discusses these results. Finally, conclusions are presented in Sect. 6 .

\section{Study area and data}

\subsection{Study area}

The study domain is in the north-east of the Iberian Peninsula and consists of the coastal zone along Catalonia and the river basins flowing into it, which are composed of the internal river basins of Catalonia and the Ebro lower river basin (Fig. 1). The coastline runs in the SE-NE direction and is bounded by the presence of two parallel mountain ranges located close to the sea: the littoral range (maximum altitude around $600 \mathrm{~m}$ a.s.l., metres above sea level) and the prelittoral range (maximum altitude around $1800 \mathrm{~m}$ a.s.1.). The northern part of the region is limited by the Pyrenees, running from west to east, with altitudes greater than 2000 ma.s.l. Therefore, the region is prone to the development of flash floods and thunderstorms (Llasat et al., 2014b), both from a hydrological point of view (existence of many small torrential catchments) and from a meteorological point of view (i.e. orographic forcing of Mediterranean air masses) (Llasat and Puigcerver, 1992). In fact, the impact of mountains on the low-level wind circulation usually triggers convective instability and affects the pressure fields (Jansà et al., 2014).

The Catalan coastline extends about $600 \mathrm{~km}$, of which $\sim 280 \mathrm{~km}$ corresponds to sedimentary coasts. The combination of the decrease in river sediment supplies, current level of urbanization and infrastructure development, and the natural littoral dynamics has led to an overall shoreline erosion during the last few decades (Jiménez and Valdemoro, 2019). From the perspective of coastal storms, the area is subjected to dominant NE-E extreme waves as well as secondary impacts from the S-SE (Mendoza and Jiménez, 2009; Bolaños et al., 2009; Mendoza et al., 2011). The NW Mediterranean is a microtidal environment with an astronomical tidal range of about $0.25 \mathrm{~m}$. Meteorological tides are of low amplitude, reaching maximum recorded values of up to $0.5 \mathrm{~m}$ during favourable conditions (under low atmospheric pressure cen- 


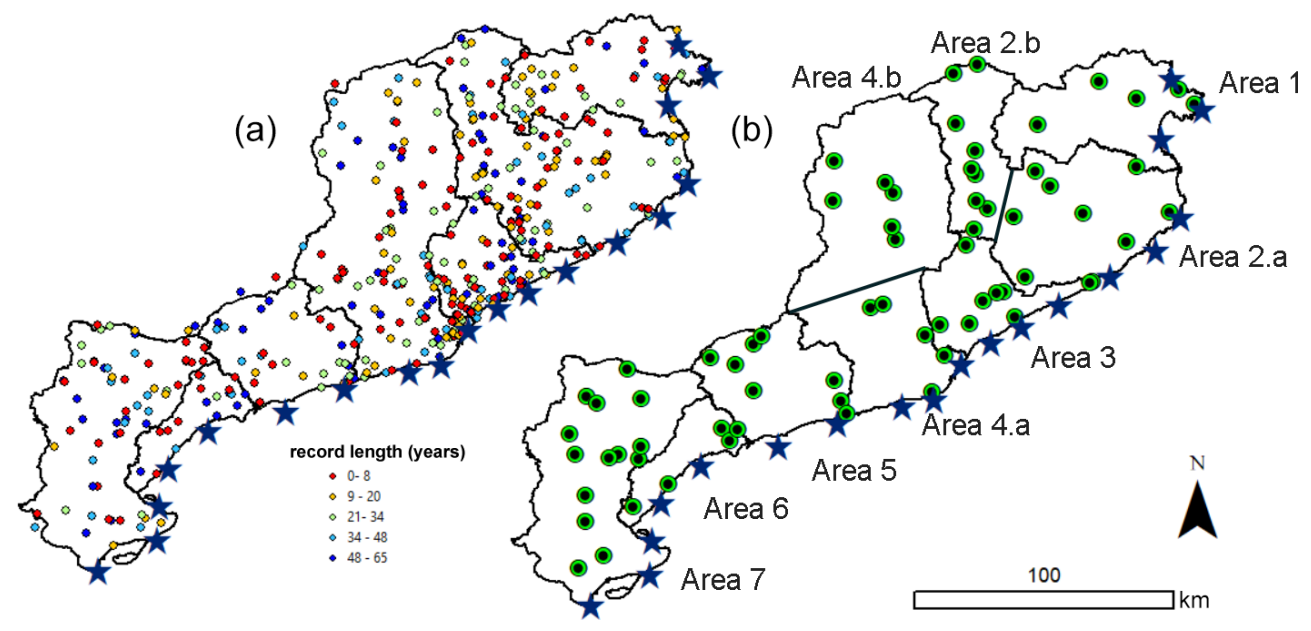

Figure 2. Location of existing rain gauges, AWSs (coloured dots), and wave nodes (stars) in the different drainage basins along the Catalan coast (a). Selected AWSs per drainage basin (areas) along the coast (b).

Table 1. Number of selected rain gauges and waves nodes in the different areas along the coast (Fig. 1).

\begin{tabular}{llrr}
\hline ID & Basin & Rain gauges & Wave nodes \\
\hline Area 1 & Girona N & 6 & 3 \\
Area 2.a & Lower Ter and Tordera & 9 & 3 \\
Area 2.b & Upper Ter basin & 9 & - \\
Area 3 & Maresme & 7 & 3 \\
Area 4.a & Lower Llobregat basin & 5 & 3 \\
Area 4.b & Upper Llobregat basin & 6 & - \\
Area 5 & Tarragona N & 8 & 2 \\
Area 6 & Tarragona S & 5 & 2 \\
Area 7 & Lower Ebro and delta & 14 & 3 \\
\hline Total & & 69 & 19 \\
\hline
\end{tabular}

tres and landward-blowing winds), in such a way that they are much lower than the wave-induced $\mathrm{Ru}$ during coastal storms (Mendoza and Jiménez, 2009). The order of magnitude of the storm-induced coastal hazards in the study area can be seen in Mendoza and Jiménez (2009) and Bosom and Jiménez (2011). Although the coastal storm intensity has not significantly changed (e.g. Casas-Prat and Sierra, 2010), the wave action on a progressively narrowing coastline has resulted in a significant increase in coastal damages during the last few decades (Jiménez et al., 2012).

To perform an integrated study of the terrestrial (rainfall) and "coastal" (waves) compound events, the study region was divided into seven areas following previous studies on flash floods (e.g. Llasat et al., 2016), dividing the region into its main groups of natural catchments along the coast (Fig. 1). Each area is composed of several river catchments and/or groups of torrential catchments flowing to their corresponding coastal stretch.

\subsection{Data}

Three main climatic datasets were used in this work to characterize the rainfall, coastal storms, and weather conditions. Rainfall was characterized using daily rainfall (P24h) data obtained from the Spanish Meteorological Agency (AEMET) database (Ramis et al., 2013), which includes records from 491 automatic weather stations (AWSs) in Catalonia (Fig. 2) covering (non-homogeneously) the period 1950-2015. The selection criteria for identifying records to be used in this analysis consisted of identifying those AWSs belonging to catchments in coastal regions with a homogeneous coverage of the 41-year period from 1973 to 2013, resulting in 69 case-study rain gauges (Fig. 2 and Table 1). Flood impacts were obtained from the INUNGAMA database, which contains all the flood events that have affected Catalonia since 1981 as well as all the catastrophic events since 1900 (Barnolas and Llasat, 2007; Llasat et al., 2016).

The wave data used were obtained from the hindcast Downscaled Ocean Waves (DOW) dataset (Camus et al., 2013), which was derived from the Global Ocean Waves dataset (Reguero et al., 2012). Data consisted of hourly values of hindcast wave conditions characterized by the significant wave height $\left(H_{\mathrm{s}}\right)$, wave period, and mean wave direction covering the same period as the rainfall data (1973-2013). The datasets were retrieved for 19 nodes located nearshore (about $20 \mathrm{~m}$ water depth), homogeneously covering the analysed basins along the coast (Fig. 1 and Table 1) to properly capture regional variations in the storm climates. Additionally, wave records during the Gloria storm in January 2020 were obtained from the SIMAR database from Puertos del Estado (http://www.puertos.es/es-es/oceanografia, last access: June 2020). 


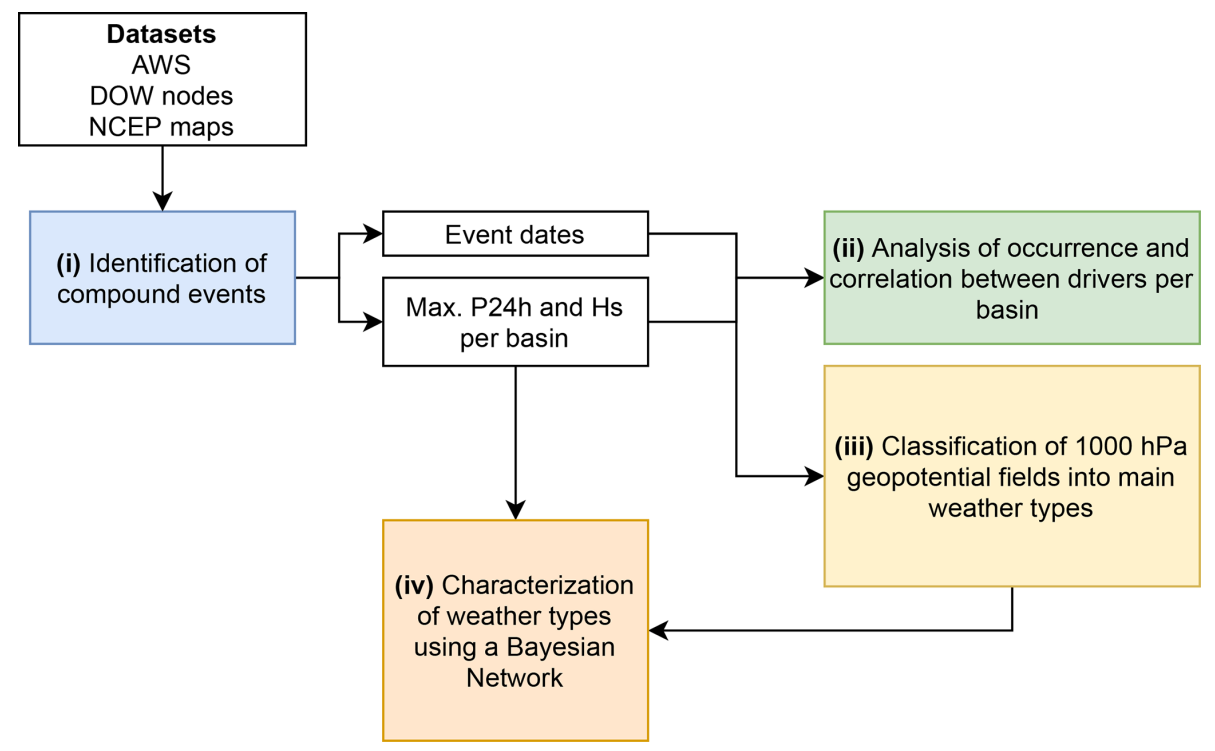

Figure 3. General methodological framework.

Weather conditions were characterized by geopotential fields at $1000 \mathrm{hPa}$ from the US National Center for Environmental Protection (NCEP) datasets. NCEP/NCAR Reanalysis I (1948-present) and NCEP/DOE Reanalysis II (1979present) generated by the National Oceanic and Atmospheric Administration (NOAA) were used. In the first case, NCEP considered the same climate model that was initialized with different types of weather sources (Kalnay et al., 1996). The second version of the first reanalysis considers the starting point of the major satellite era, which implies that more observations included fewer errors in the resulting fields (Kanamitsu et al., 2002). To retrieve weather data from the NCEP/NCAR Reanalysis datasets, we used the RNCEP library of R-Cran (Kemp et al., 2012). The fields were collected for a spatial extent covering longitudes -25 to $29^{\circ}$ and latitudes 30 to $64^{\circ}$, with a spatial resolution of $2.5^{\circ} \times 2.5^{\circ}$ $(N=13 \times 15$ grid) covering the period 1973-2013 with a temporal resolution of $6 \mathrm{~h}$.

\section{Methods}

\subsection{General framework}

The general methodological framework adopted in this study consisted of the following steps (Fig. 3):

i. Compound events are identified. First, individual heavy rainfall and coastal storm episodes are identified at all rain gauges and coastal nodes. Then, compound events are defined by identifying dates upon which the two considered drivers co-occur along the territory. Extreme events with only "pure" coastal storms without rain or pure rain episodes without waves are discarded. Each compound event is characterized in terms of a representative $H_{\mathrm{S}}$ (the maximum value reached during the event) and daily precipitation (P24h) per coastal basin.

ii. The results from (i) are used to assess the frequency of occurrence and spatial distribution of the different event types (multivariate and spatially compounding). At this stage, the correlation between driver intensity (i.e. the correlation between the maximum $H_{\mathrm{s}}$ and P24h) is also analysed for both event types.

iii. Compound event dates obtained in (i) are used to retrieve $1000 \mathrm{hPa}$ geopotential maps, which are then classified using correlation-based techniques to determine the main associated weather types. Notably, an event can be associated with different weather types throughout its lifetime.

iv. The results in (i) and (iii) are combined by feeding a Bayesian network (BN) to characterize each weather type in terms of the spatial distribution of the multivariate and spatially compounding events and the probabilities of exceedance of driver intensities ( $\mathrm{P} 24 \mathrm{~h}$ and $H_{\mathrm{s}}$ ).

\subsection{Identification of extreme events}

The first step consisted of identifying individual extreme events from selected rain and wave datasets (Fig. 1). This was done by applying the peak over threshold (POT) method to daily rainfall (P24h, in $\mathrm{mm}$ ) and to significant wave height $\left(H_{\mathrm{s}}\right)$ as representative climate variables of the compounding drivers: heavy rainfall and coastal storms.

Following previous studies in the area (Barbería et al., 2014; Cortès et al., 2018), potential extreme rainfall episodes 
were identified using a P24h of $40 \mathrm{~mm}$ and a $3 \mathrm{~d}$ interval between consecutive events to identify independent episodes. Although the daily threshold is below the value used by some international projects such as MEDEX (Jansà et al., 2014 proposed $60 \mathrm{~mm}$ ), local flash floods and urban floods can be produced when this precipitation falls within less than $2 \mathrm{~h}$. The event is then characterized by the maximum recorded P24h value. A second threshold of $100 \mathrm{~mm}$ was used to flag severe extreme events to later differentiate them during the characterization assessments. This threshold has previously been used in the region when studying extreme rainfall associated with large riverine flooding (Gilabert and Llasat, 2018).

Coastal storms were identified using a double-threshold POT (see Sanuy et al., 2019). The 98th percentile of the $H_{\mathrm{s}}$ time series is used as the first filter to locate storm start and end times, which roughly correspond to $H_{\mathrm{s}}=2 \mathrm{~m}$, in agreement with Mendoza et al. (2011) for NW Mediterranean conditions. Then, an upper threshold given by the 99.5 th percentile is applied to retain only extreme storms. This criterion results in class III storms according to the Mendoza et al. (2011) classification, which corresponds to the minimum required conditions to produce significant impacts on the coast (i.e. erosion and inundation; see Mendoza and Jiménez, 2009). In addition, a $3 \mathrm{~d}$ interval of fair-weather conditions between consecutive events was used to identify independent episodes.

The result of this step is a collection of heavy rainfall and wave storm individual episodes for all AWSs and wave nodes. Each episode is characterized by an initial and final date and the maximum values of P24h and $H_{\mathrm{s}}$ for rainfall and waves, respectively.

\subsection{Compound event classification and occurrence}

The second step consisted of identifying and characterizing compound events in each area along the coast (Fig. 2). First, we established the occurrence of a coastal (wave) storm event by comparing the storm initial time at all coastal nodes within a $24 \mathrm{~h}$ window. All storms within such a window were considered a single event, which is labelled with the same date, and they should correspond to a coastal storm propagating along the territory. Then, all rain gauges were surveyed to identify the occurrence of heavy rainfall episodes during the identified coastal (wave) storm and in the $3 \mathrm{~d}$ before. If no heavy rainfall is recorded at any rain gauge, the event is removed from the analysis, as it would correspond to a pure wave storm. On the contrary, if any station records an extreme P24h episode, the event is flagged as a compound event, with its date of occurrence being given by the earliest starting time of coastal storms at any node. Finally, each compound event is characterized by the maximum P24h and $H_{\mathrm{s}}$ values at the stations and nodes within each coastal area and during the event duration.
As a result of this process, a compound event is identified herein when a heavy rainfall episode at any station along the coast occurs simultaneously, or in rapid succession (within a $3 \mathrm{~d}$ interval), with extreme waves at any location along the coast. Therefore, an identified compound event at a given time may present different characteristics along the costal basins (hereafter also named areas or sectors): areas in which rainfall and wave extreme events simultaneously cooccur, areas with only one extreme component (either rain or waves), and areas without any extreme episodes. Then, each compound event is characterized along the coast (in each sector) as follows: (i) multivariate (simultaneous rainfall and wave episodes); (ii) spatially compounding (SC) rain, where local extreme conditions correspond to rainfall; and (iii) spatially compounding (SC) waves, where local extreme conditions correspond to storm waves. The classification intends to classify the event as it is experienced in each basin. Thus, in the face of a compound event (regional scale), there will be basins that experience it as multivariate (both components co-occur) and basins that experience it as spatially compounding. In the second case, the basin may be receiving only rain (SC-rain) or only waves (SC-waves). According to our definition of a compound event, there will always be a co-occurrence of the two components at the regional scale.

\subsection{Intensity correlation analysis}

To investigate the correlation between the magnitude of both components of the compound event, $\mathrm{P} 24 \mathrm{~h}$ and $H_{\mathrm{s}}$, across all areas, we used the Spearman $\rho$ coefficient (e.g. Genest and Favre, 2007); this is defined as the Pearson correlation coefficient between the variable ranks (Eq. 1). The correlation of the wave magnitude $\left(H_{\mathrm{S}}\right)$ at each coastal area with the P24h rainfall at each of the nine areas is calculated as follows:

$\rho=\frac{\operatorname{cov}\left(\operatorname{rg}_{H_{\mathrm{s}}}, \operatorname{rg}_{\mathrm{P} 24 \mathrm{~h}}\right)}{\sigma_{\mathrm{rg}_{H_{\mathrm{s}}}} \sigma_{\mathrm{rg}_{\mathrm{P} 24 \mathrm{~h}}}}$,

where $\operatorname{rg}_{H_{\mathrm{S}}}$ and $\mathrm{rg}_{\mathrm{P} 24 \mathrm{~h}}$ are the ranks of $H_{\mathrm{S}}$ and $\mathrm{P} 24 \mathrm{~h}$, respectively, cov is the covariance, and $\sigma$ is the standard deviation.

\subsection{Synoptic typology}

During the development of a compound event, different weather types can be present; in this study, we therefore use corresponding pressure fields (geopotential height at $1000 \mathrm{hPa}$ ) at the closest time to the date-time assigned to each event (Sect. 3.3). Weather conditions were then classified by applying a correlation-based method (Yarnal, 1993; Wu et al., 2018) to the $1000 \mathrm{hPa}$ geopotential height field. The method consists in obtaining map patterns using the Pearson product-moment correlation $\left(r_{x y}\right.$, Eq. 2$)$ to depict the degree of similarity of spatial structures between pairs of gridded data (i.e. the map typing focuses on the positions of high- and low-pressure centres, rather than their magnitudes). All maps were extracted at the closest time to the be- 


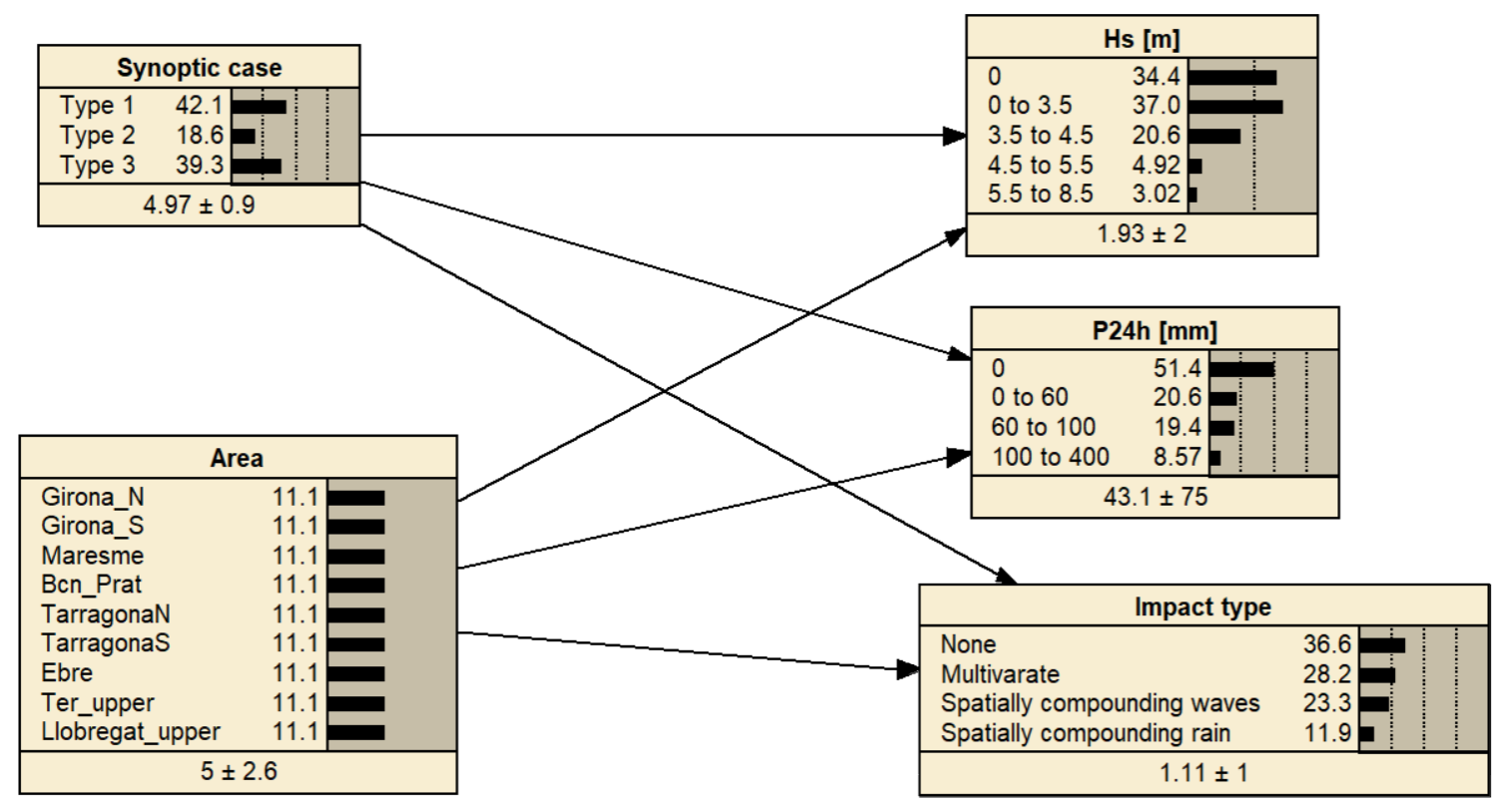

Figure 4. BN configuration used to characterize the system behaviour. The severity of the compounding forcing $\left(H_{\mathrm{S}}\right.$ and $\left.\mathrm{P} 24 \mathrm{~h}\right)$ and the presence of multivariate or spatially compounding (wave or rain only) effects are conditioned to the synoptic case (weather type) and area (basin/coastal sector).

ginning of the compound event, as defined in Sect. 3.4 (i.e. the beginning of the coastal storm).

First, all maps are normalized via $\mathrm{Zi}=\left(z_{i}-\bar{z}\right) / \sigma_{z}$, where $\mathrm{Zi}$ represents the number of positive or negative standard deviations from the mean at each grid cell $i, z_{i}$ is the original value at grid point $i$, and $\bar{z}$ and $\sigma_{z}$ are the mean and standard deviation of the $N=13 \times 15$ grid point values. Once normalized, each map is compared with all other maps using

$r_{x y}=\frac{\sum_{i=1}^{N}\left[\left(x_{i}-\bar{x}\right)\left(y_{i}-\bar{y}\right)\right]}{\sqrt{\sum_{i=1}^{N}\left(x_{i}-\bar{x}\right)^{2}\left(y_{i}-\bar{y}\right)^{2}}}$,

where $x_{i}$ and $y_{i}$ represent the normalized value at each of the $N$ points of the pair of maps being compared, and $\bar{x}$ and $\bar{y}$ are the corresponding means across the $N$-point grids. A pair of maps is considered similar when $r_{x y} \geq \mathrm{rt}$, where $\mathrm{rt}$ is a correlation threshold. Different sources of subjectivity exist in choosing the value of rt (Yarnal et al., 1993), which usually depends on a balance between the number of identified patterns and the number of dates (events) remaining without classification.

The process was applied as described by Wu et al. (2018). The first date of the reference is used as the key day, and all maps are compared to create the first class. Then, all classified dates are removed, and another date from the nonclassified pool is used as the second key day. A value of $\mathrm{rt}=0.2$ was used in this step, which led to four weather-type candidates. Then, a second comparison between each individual map and the average of each group candidate was performed to ensure that maps that are similar to more than one type are classified into the group corresponding to a maximum $r_{x y}$. This led to a final three-group classification with a mean $r_{x y}$ of $0.64-0.7$ per group.

\subsection{BN-based classification}

BNs are statistical tools based on acyclic graph theory and Bayes' theorem (Pearl, 1988; Jensen, 1996) and have demonstrated their versatility and utility in efficiently combining multiple variables to predict or characterize system behaviour (e.g. Gutierrez et al., 2011; Plant et al., 2016; Beuzen et al., 2018). The BN is used here to assess the probabilistic relationship between each type of meteorological forcing (Sect. 3.5) and their associated effects (multivariate or spatially compounding) and driver intensities ( $H_{\mathrm{S}}$ and P24h) at each of the different basins.

Figure 4 shows the BN structure, the considered variables, and the variable discretization. The arrows depict the parentchild relationships; i.e. the results will be presented in terms of the probability of given values of $H_{\mathrm{s}}, \mathrm{P} 24 \mathrm{~h}$, and impact type conditioned to the different possible combinations of the synoptic case and area. The training dataset consisted of 1260 variable combinations resulting from the previous assessment of 140 compound events in nine different areas. 
Table 2. Number of compound events per type of occurrence of climatic drivers at each basin.

\begin{tabular}{llrrrr}
\hline ID (Fig. 1) & Basin & Multivariate & SC-waves & SC-rain & No driver \\
\hline Area 1 & Girona N & 70 & 16 & 19 & 35 \\
Area 2.a & Lower Ter and Tordera & 76 & 14 & 28 & 22 \\
Area 2.b & Upper Ter basin & $3(*)$ & - & $5(*)$ & $132(*)$ \\
Area 3 & Maresme & 43 & 48 & 17 & 32 \\
Area 4.a & Lower Llobregat basin & 36 & 58 & 18 & 28 \\
Area 4.b & Upper Llobregat basin & $4(*)$ & - & $0(*)$ & $136(*)$ \\
Area 5 & Tarragona N & 34 & 57 & 20 & 29 \\
Area 6 & Tarragona S & 35 & 65 & 15 & 25 \\
Area 7 & Lower Ebro and delta & 54 & 36 & 28 & 22 \\
\hline
\end{tabular}

Upper basins (not directly affected by waves) are marked as $(*)$, where a threshold of P24h $>100 \mathrm{~mm}$ is used.

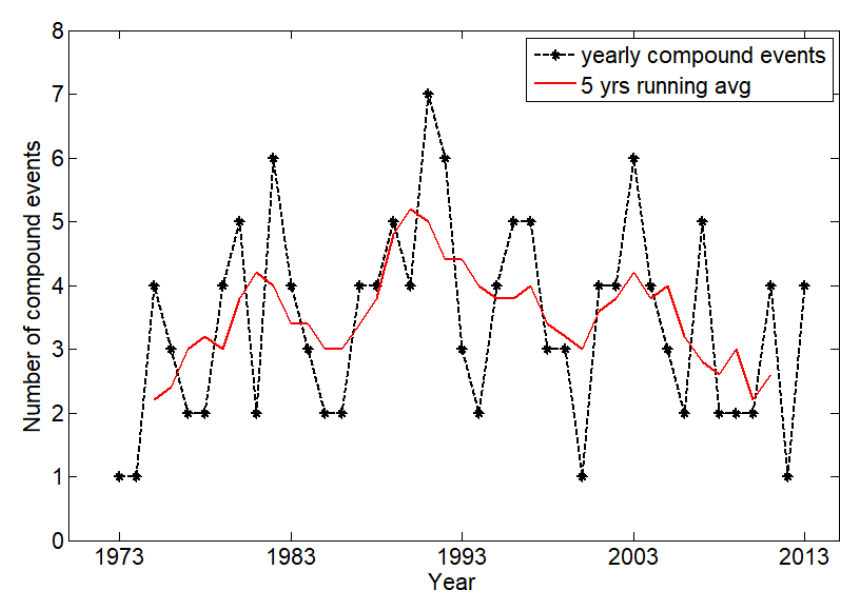

Figure 5. Annual number of compound events (black) and the running 5-year average (red) for the period 1973-2013.

\section{Results}

\subsection{Frequency and location of compound events}

During the analysed 1973-2013 period, 225 coastal storms and 605 heavy rainfall episodes affecting at least one of the considered areas were identified. It must be considered that the real number of rainfall events would be higher, since convective localized episodes are under-represented in the dataset used. From this total, 140 episodes can be classified as compound events in which wave storms are accompanied by heavy rainfall in any area along the coast. This means that $62 \%$ of coastal storms and $23 \%$ of heavy rainfall episodes can be labelled as compound events and that the probability of having such compounding conditions is larger under coastal (wave) storms. The average frequency of occurrence along the Catalan coast during the study period was 3.4 compound events per year, without presenting any statistically significant trend during the 41 years analysed (Fig. 5).

Figure 6 and Table 2 show the spatial distribution of the 140 identified compound events along the Catalan coast ac- cording to their typology as locally recorded: multivariate (simultaneous rainfall and wave storm episodes in the same area), SC-waves (a solo wave storm episode in a given area with simultaneous heavy rainfall co-occurring in a different area), and SC-rain (a solo rainfall episode in a given area with a simultaneous wave storm co-occurring in a different area). In addition, the local absence of extreme conditions for both drivers was retained.

The results show that, in the presence of a compound event along the Catalan coast, areas with the highest probability of experiencing a multivariate event are in the northernmost part, Girona N, and the Lower Ter-Tordera basins (with an occurrence frequency of about $55 \%$ ) followed by the southernmost end in the lower Ebro basin and delta (with an occurrence frequency of about $40 \%$ ). On the other hand, although the areas located at the central part of the coast show a non-negligible probability (about $20 \%-30 \%$ of recorded events) of experiencing multivariate events, they are dominated by the presence of spatially compound events with the local presence of wave storms (about $40 \%-50 \%$ of recorded events). These results would indicate that, in the study area, when a regional compound event occurs, wave storms are the "spatially dominant" driver, with all areas along the coast having a probability greater than $60 \%$ of having local wave storms (either multivariate or SC-waves). On the other hand, areas presenting a high probability ( $>60 \%$ ) of having rainfall extremes (either multivariate or SC-rain) during regional compound events are restricted to the two northernmost areas and the southernmost one ( $58 \%)$; the central part of the coast (Areas 3 to 6) presents relatively low probabilities of experiencing extreme rainfall ( $35 \%-42 \%)$. All percentages given are relative to the total number of identified compound events.

Rainfall events in the terrestrial areas which correspond to the Ter and Llobregat upper basins (areas $2 b$ and $4 b$ ) are filtered with $\mathrm{P} 24 \mathrm{~h}>100 \mathrm{~mm}$ to assess their potential effects at the coastal fringe; fewer than $5 \%$ of cases reach those precipitation levels in combination with extreme waves at the coast (Table 2). 


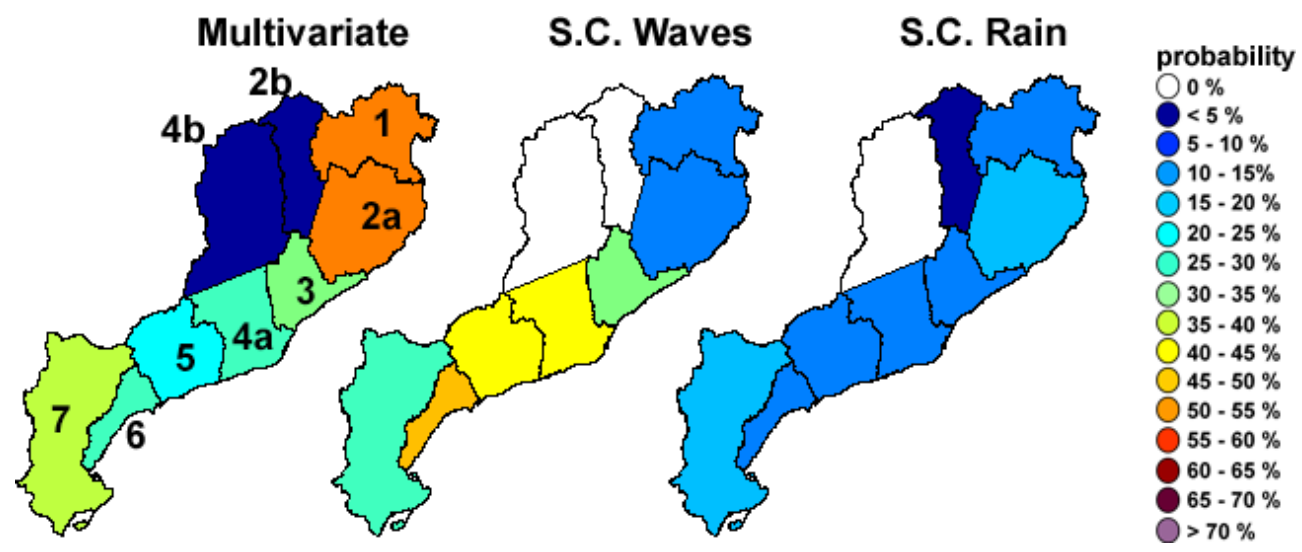

Figure 6. Probability of occurrence of the different types of compound events along the Catalan coast. Multivariate (local simultaneous rainfall and wave storm episodes); SC-waves (local wave storm episodes and simultaneous rainfall in a different area); SC-rain (local rainfall episode and simultaneous wave storm in a different area). Probabilities are given with respect to the presence of a compound event (average

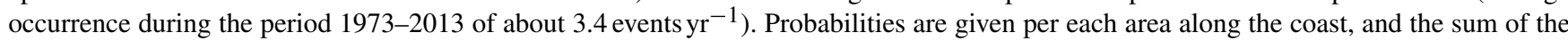
different types of events per area does not necessarily reach $100 \%$ due to cases in which neither rainfall nor wave storms locally occur. Area numbers are specified on the map on the left.
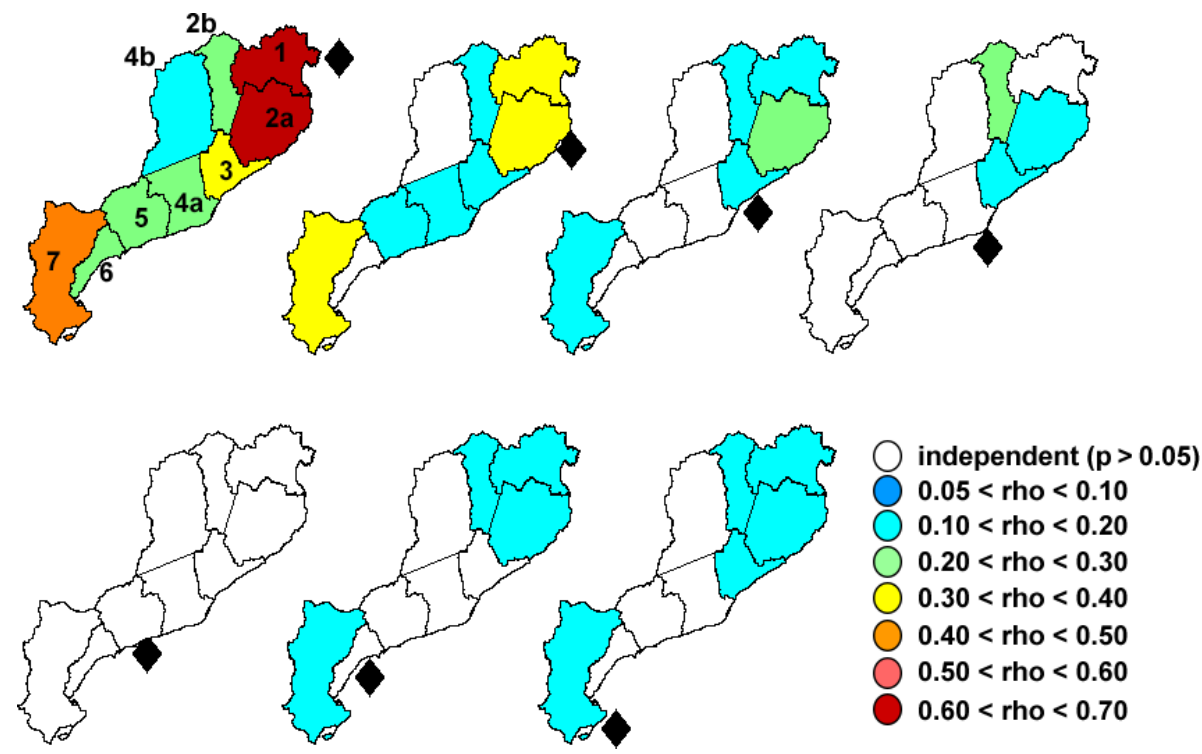

Figure 7. Correlation values (Spearman $\rho$ ) between the $H_{\mathrm{S}}$ magnitude and P24h during compound events. Each map shows the correlation between the waves $\left(H_{\mathrm{S}}\right)$ in the area indicated by the diamond and rainfall in the other areas. White areas indicate that variables are statistically independent at a significance level of 0.05 . Area numbers are specified on the top left map.

\subsection{The correlation between wave components and rainfall intensity during compound events}

Once the probability of occurrence of compound event was analysed at different areas along the coast, the correlations among the magnitude of the climatic drivers (rainfall and waves) needed to be determined. Figure 7 shows the computed Spearman $\rho$ coefficient by correlating the waves $\left(H_{\mathrm{S}}\right)$ in a given area (marked with a diamond in the figure) with rainfall (P24) at all areas along the coast.
The results show that, in general, the correlation between the intensity of local wave storms and rainfall across the territory (measured as peak values of $H_{\mathrm{s}}$ and P24h during the event) decreases from north to south, following the observed trend in the dominance of multivariate events. The highest correlation value $(\rho=\sim 0.65)$ was obtained for multivariate events in the northernmost area (Fig. 7), suggesting a strong link between locally simultaneous wave storms and rainfall. The connection between these drivers extends southwards in such a way that the correlation between the wave storm intensity in Area 1 with simultaneous rainfall episodes in the 

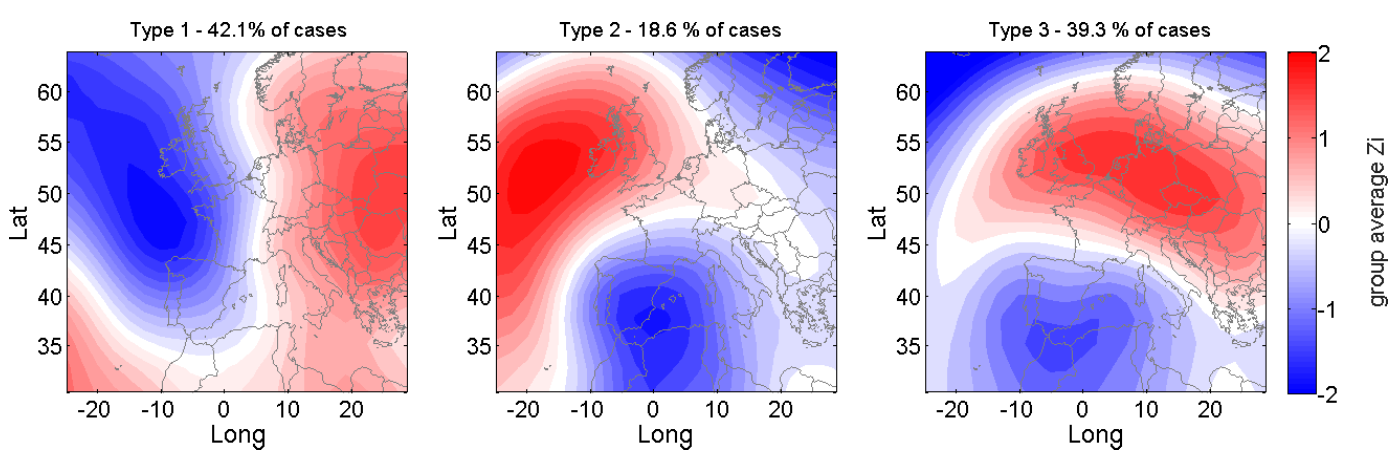

Figure 8. Synoptic types during the occurrence of compound extreme events along the Catalan coast based on the correlation between the $1000 \mathrm{hPa}$ geopotential fields (coloured shading). The group average $\mathrm{Zi}$ represents the mean number of positive or negative standard deviations from the mean at each grid cell $i$.

adjacent Area 2 is of the same order of magnitude. The correlation progressively decreases southward as we compare it with the rainfall recorded in the central basins, but, in all cases, the correlation is statistically different from zero. Notably, a value of $\rho>0.4$ is obtained in the southernmost sector, where the presence of multivariate events is higher than in the central basins.

When the intensity of wave storms recorded in Area 2 is correlated with rainfall across the territory during compound events (Fig. 7), a similar behaviour than that in Area 1 is observed, although with lower correlation values. As we progressively move to the south, the correlation between the intensity of the local wave storms and P24h at any area consistently decreases to very low values or, directly, they are statistically uncorrelated. On a regional scale, the central basins have the lowest values of $\rho$, suggesting an independence of storm waves and intense rainfall events.

\subsection{Synoptic conditions}

Weather conditions during the 140 identified compound events were classified in three different synoptic types (Fig. 8). Synoptic type 1 conditions prevail during $42.1 \%$ of cases and are characterized by the presence of lower pressures north-west of the Iberian Peninsula over the Atlantic Sea and higher pressures in the central Mediterranean. The deep low in the north-western part of the Iberian Peninsula and the strong anticyclone over central Europe favour a strong pressure gradient and consequently induce intense winds from the south (Llasat, 1987). This type of situation usually creates a mesoscale structure when the deep low and strong anticyclone impinge over the Pyrenees range, known as an orographic dipole, with a mesoscale high over Catalonia that modifies the synoptic pressure field and creates an eastern component of the wind that favours the entrance of warm and wet air. At the same time, the mountain range triggers potential instability and develops convective systems and heavy rainfall (Trapero et al., 2013; Llasat et al., 2014b).
Synoptic type 2 (18.6\% of cases) is characterized by the presence of a depression in the south-eastern Iberian Peninsula and an anticyclone in the north-west, which creates a strong pressure gradient and N-NE winds. This kind of meteorological situation is more effective in generating sea storms than it is in generating heavy rainfall. Synoptic type 3 conditions (39.3\% of cases) are similar to those of type 2, with a deep low in the southern Iberian Peninsula and an anticyclone to the north-east. The main difference is that this anticyclone is placed over the centre of Europe in this type; this pattern gives rise to a strong E-SE wind at low levels.

\subsection{Compound event characteristics under each synoptic type}

The BN was used to calculate the probability of occurrence of multivariate and spatially compounding (wave or rainfall) events in different areas given the different synoptic types (Fig. 9). The BN was also used to calculate the probability of exceedance of significant thresholds of $H_{\mathrm{S}}$ and P24h for each type of compound event at the different areas along the coast to assess the intensity of each contributing component (Fig. 10).

Under a meteorological forcing generated by synoptic type 1 , which is the most likely to occur, the probability of occurrence of multivariate events anywhere in the territory is the lowest compared to that associated with the other types (Fig. 9). Moreover, when multivariate events occur, they are concentrated in the northernmost part of the coast (areas 1 and 2). In the rest of the coast, the dominant event is SC-waves. Generated wave storms present the smallest $H_{\mathrm{S}}$ values along the territory, without inducing extreme storms $\left(H_{\mathrm{S}}>5.5 \mathrm{~m}\right)$ (Fig. 10). On the other hand, the probability of SC-rain events is higher than in the other types, especially in the Ebro basin. Moreover, it is the most likely to exceed a P24h of $100 \mathrm{~mm}$.

Synoptic type 2 episodes are more prone to create Levante (winds blowing from the east) situations, during which the probability of occurrence of multivariate events increases, es- 

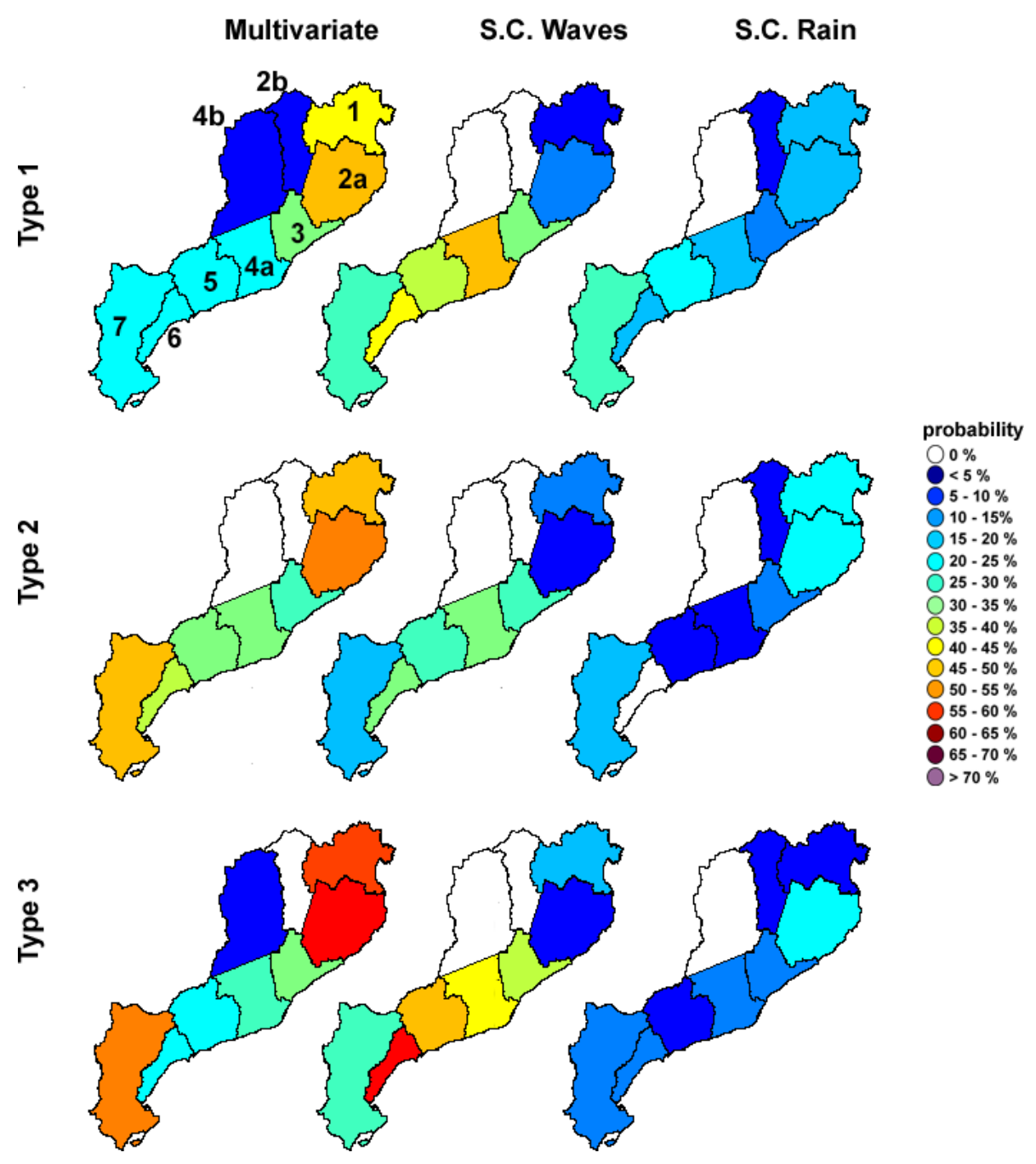

Figure 9. Spatial distribution of the probability of occurrence of the different types of compound events conditioned to each synoptic type. Probabilities are given per each area along the coast, and when adding the different types of events per area, they do not necessarily reach $100 \%$ due to cases in which neither rainfall nor wave storms locally occur. Area numbers are specified on the top left map.

pecially in the northern and southern areas, while in the central part of the coast, multivariate and SC-waves are equally probable (Fig. 9). The severity of coastal storms $\left(H_{\mathrm{s}}\right)$ increases, especially at the northern and southern ends, where extreme storms $\left(H_{\mathrm{S}}>5.5 \mathrm{~m}\right)$ have been recorded (Fig. 10). The probability of rainfall episodes with $\mathrm{P} 24 \mathrm{~h}>40 \mathrm{~mm}$ increases in the same areas with respect to type 1 , whereas the frequency of the most intense episodes (P24h $>100 \mathrm{~mm})$ decreases, except for Area 1 (Fig. 10).

Synoptic type 3 is similar to type 2 in that it also represents Levante situations but is characterized by the marked southnorth pressure gradient, which results in significant windstorms and strong waves. Consequently, they present similar overall probabilities of occurrence of multivariate events along the coast, with type 3 presenting a larger probability of multivariate occurrence at the northern and southern extremes and a higher frequency of SC-waves, especially in the central areas (Fig. 9). In terms of intensity, wave storms recorded under synoptic type 3 present the highest probability of exceeding $H_{\mathrm{s}}>3.5 \mathrm{~m}$ in all areas and the highest probability of extreme waves $\left(H_{\mathrm{s}}>5.5 \mathrm{~m}\right)$, which is restricted to the two northernmost areas (Fig. 10). On the other hand, the distribution of probability of P24h exceeding 40 or $100 \mathrm{~mm}$ is very similar to type 2 , since in both cases there is an incidence of a warm and humid air mass from the east.

\subsection{Compound event characteristics based on historical events}

Differences in weather patterns result in events with different characteristics and, consequently, impacts throughout the territory. To put the potential consequences of these events in the context of risk management, the impact of selected events recorded in the study area under the different synop- 


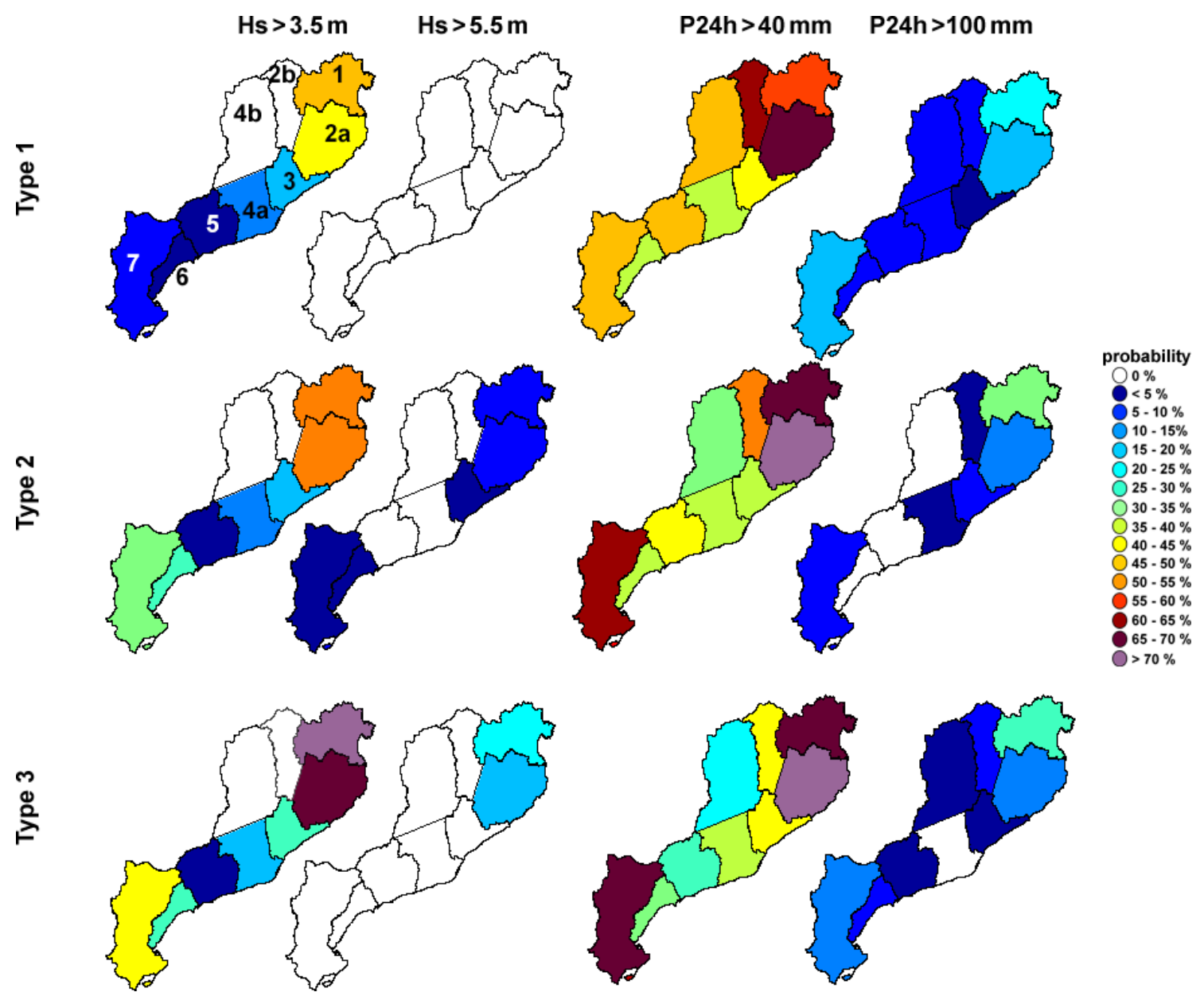

Figure 10. Spatial distribution of the probability of exceedance for different thresholds of $H_{\mathrm{S}}(3.5$ and $5.5 \mathrm{~m})$ and $\mathrm{P} 24 \mathrm{~h}(40$ and $100 \mathrm{~mm})$ conditioned to each synoptic type. Area numbers are specified on the top left map.
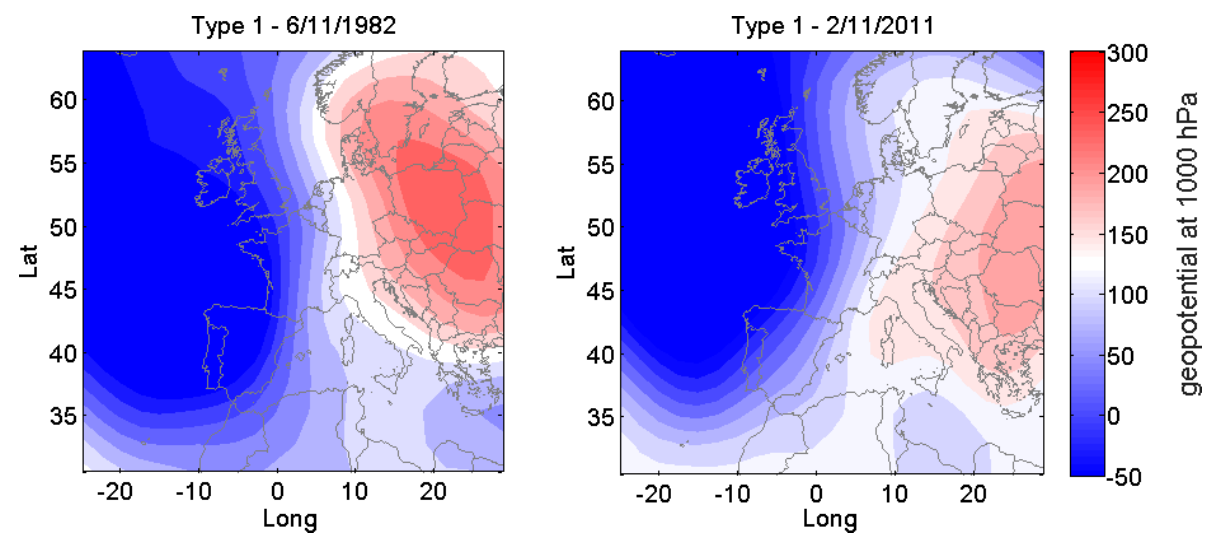

Figure 11. Maps of the $1000 \mathrm{hPa}$ geopotential fields of type 1 events extracted at the time closest to the start of the coastal storm.

tic types is illustrated with information gathered from afterevent press coverage and the INUNGAMA and PRESSGAMA databases (Llasat et al., 2009, 2014a; Jiménez et al., 2012). Synoptic conditions during each analysed event are shown in Figs. 11 and 12, with maps being extracted follow- ing the criteria described in the methodological framework. Table 3 shows the maximum $H_{\mathrm{s}}$ and $\mathrm{P} 24 \mathrm{~h}$ recorded in each area along the coast during each event. Two representative events were chosen for types 1 and 3 , as they occur twice as 

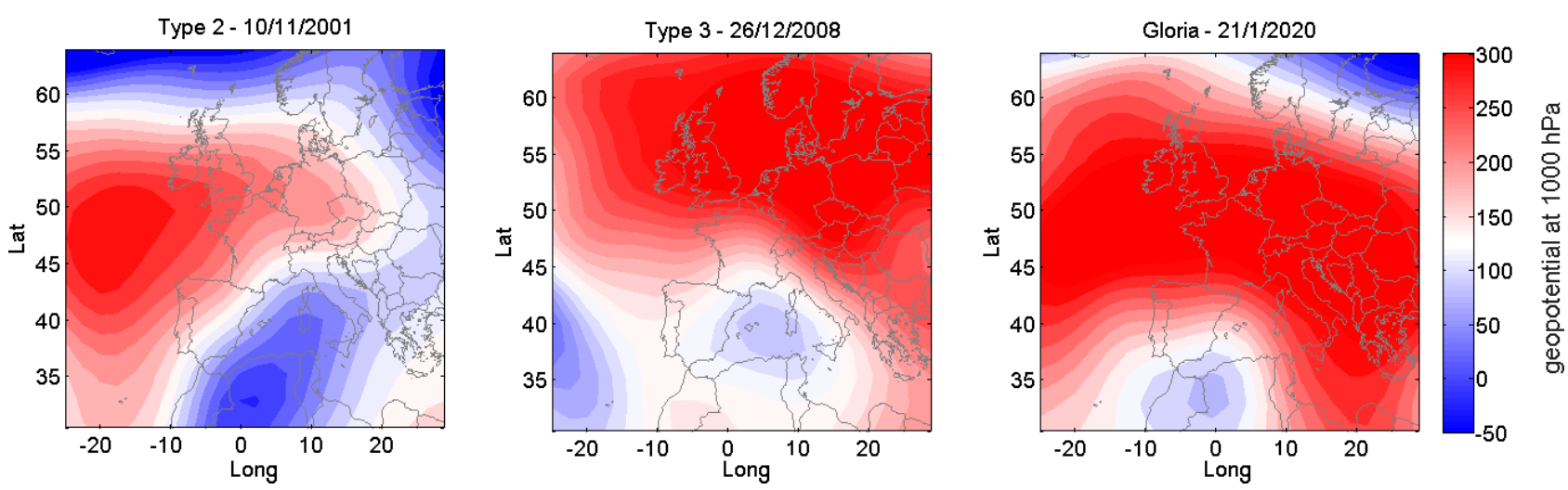

Figure 12. Maps of the $1000 \mathrm{hPa}$ geopotential fields (shades) of type 2 and type 3 events extracted at the time closest to the start of the coastal storm.

Table 3. Values of the maximum $H_{\mathrm{S}}(\mathrm{m})$ and $\mathrm{P} 24 \mathrm{~h}(\mathrm{~mm})$ for each selected event (Figs. 11 and 12) along the study area extracted from the analysis dataset. Data on Gloria (outside the dataset) were extracted from the SIMAR wave database (Puertos del Estado) and XEMA rain gauge system (SMC). Note that the $H_{\mathrm{S}}$ values given for Gloria do not belong to the same database as the other storms do; consequently, their values are not absolutely equivalent. Values in bold highlight $H_{\mathrm{S}}>5 \mathrm{~m}$ and P24h $>100 \mathrm{~mm}$, respectively.

\begin{tabular}{|c|c|c|c|c|c|c|c|c|c|c|}
\hline & \multicolumn{4}{|c|}{ type 1} & \multirow{2}{*}{\multicolumn{2}{|c|}{$\frac{\text { type } 2}{10 \text { Nov } 2001}$}} & \multicolumn{4}{|c|}{ type 3} \\
\hline & \multicolumn{2}{|c|}{6 Nov 1982} & \multicolumn{2}{|c|}{2 Nov 2011} & & & 26 & ec 2008 & $21 \mathrm{Jan}$ & 020 (Gloria) \\
\hline & $H_{\mathrm{S}}(\mathrm{m})$ & $\mathrm{P} 24 \mathrm{~h}(\mathrm{~mm})$ & $H_{\mathrm{S}}(\mathrm{m})$ & $\mathrm{P} 24 \mathrm{~h}(\mathrm{~mm})$ & $H_{\mathrm{S}}(\mathrm{m})$ & $\mathrm{P} 24 \mathrm{~h}(\mathrm{~mm})$ & $H_{\mathrm{S}}(\mathrm{m})$ & P24h (mm) & $H_{\mathrm{S}}(\mathrm{m})$ & $\mathrm{P} 24 \mathrm{~h}(\mathrm{~mm})$ \\
\hline Area 1 & 5.4 & 78 & - & 93 & 7.9 & 107 & 8.0 & 203 & 7.2 & 101 \\
\hline Area 2.a & 4.6 & 98 & - & 46 & 8.1 & 81 & 7.8 & 120 & 6.1 & 204 \\
\hline Area 2.b & & 196 & & 83 & & 57 & & 43 & & 148 \\
\hline Area 3 & 4.3 & 116 & - & 56 & 6.0 & - & 5.4 & 60 & 6.0 & 115 \\
\hline Area 4.a & 3.9 & 69 & 2.3 & 56 & 5.3 & 49 & 4.3 & 52 & 6.6 & 136 \\
\hline Area 4.b & & & & 133 & & 59 & & - & & 131 \\
\hline Area 5 & 3.4 & 50 & 2.4 & 82 & 4.0 & 48 & 2.8 & 47 & 5.4 & 154 \\
\hline Area 6 & 3.1 & - & 2.4 & - & 5.5 & 50 & 3.8 & - & 6.3 & 126 \\
\hline Area 7 & 3.3 & - & 2.5 & - & 5.6 & 46 & 3.9 & 41 & 7.6 & 209 \\
\hline
\end{tabular}

frequently as type 2 events do, which are only represented here by one event.

Between 6 and 8 November 1982, a compound event generated under a type 1 synoptic situation (Fig. 11) took place along the Catalan coast. From a meteorological point of view, the event was dynamically forced, as it unfolded in the prefrontal and frontal zones of a strong Atlantic baroclinic storm, although the Pyrenees played a relevant role by triggering deep convection. The largest contribution of humidity was from the Atlantic (mainly tropical and subtropical regions but also from the north), with relevant additional input from the western Mediterranean (Insua-Costa et al., 2019). This was a very extensive episode of heavy rain affecting Portugal, Spain, Andorra, and France. Catastrophic flash floods and landslides occurred in the Upper Llobregat basin (Area 4.b) and Upper Ter basin (Area 2.b) (Puigdefàbregas, 1983; Llasat, 1987), where nearly 342 and $556 \mathrm{~mm}$ were recorded in less than 24 and $72 \mathrm{~h}$, respectively. The Llobregat River (Areas 4.a and 4.b) recorded a peak flow of
$1600 \mathrm{~m}^{3} \mathrm{~s}^{-1}$ near its mouth when its average discharge was $328 \mathrm{~m}^{3} \mathrm{~s}^{-1}$.

The main peak rainfall and wave conditions recorded during the event along the Catalan coast are shown in Table 3. As can be seen, although waves exceeded storm threshold conditions along the entire coast, their values were relatively low, with only the northernmost sector presenting severe storm conditions according to the Mendoza et al. (2011) classification. Due to this, coastal-storm-induced damages were relatively low and were limited to some stretches at Costa Brava (Areas 1 and 2.a), where waves induced minor damage to some marina facilities and caused overtopping at some beach waterfronts. Some beaches in the Maresme region (Area 3) were also affected, with extensive erosion and overtopped promenades. On the other hand, the rainfall-induced damage was extensive and very important, with 14 casualties and EUR 1033 million (adjusted for 2020) of private flood damages paid by the Insurance Compensation Consortium (the Spanish public re-insurance company, CCS) as a consequence of the floods in Catalonia (throughout the entire terri- 
tory and not only in coastal areas). In summary, although this was a multivariate event at many basins, the most important and relevant damage was caused by rainfall-induced floods (Fig. 12).

Another significant type 1 event occurred in 2011, starting on 2 November and lasting until 7 November 2011 (Fig. 11). It mainly affected Catalonia (Spain) and Liguria (Italy). In the first region, the maximum cumulative rainfall was $326 \mathrm{~mm}$ (close to Area 2.b, Table 3), while the maximum in $24 \mathrm{~h}$ was $203 \mathrm{~mm}$ (close to Area 4.b, Table 3). It produced a flood in the Muga River (Area 1), with a peak discharge of $378 \mathrm{~m}^{3} \mathrm{~s}^{-1}$ near the mouth (on 1 November the flow was $0.7 \mathrm{~m}^{3} \mathrm{~s}^{-1}$ ) (Llasat et al., 2014a). Between 2 and 8 November, the CCS paid EUR 2.1 million (adjusted for 2020) for damages produced by the sea storm and EUR 458.8 million (adjusted for 2020) for damages produced by floods in insured assets. Meteorological features showed the presence of a trough at $500 \mathrm{hPa}$ associated with a synoptic frontal wave that evolved into a mesoscale depression along the Catalan coast on 6 November. This situation favoured the entrance of very warm and wet air from the south-east over Catalonia and humidity advection from the Atlantic.

It should be noted that both events presented similar characteristics, with the most important contribution to damage being induced by rainfall. On the other hand, combined/compound effects were scarcely reported in just few areas, where they locally induce a moderate-to-high impact.

An historical compound event generated under type 2 conditions in the area occurred in November 2001 (Fig. 12), when a thermal orographic low over the African plateau interacted with an upper-level trough and developed a strong cyclone that moved toward the Mediterranean Sea over Algiers following a northward trajectory, creating torrential rainfalls and floods in Algiers (more than 700 deaths). When the cyclone reached the sea, the low reached its mature state (Fita et al., 2006; Genovés and Jansà, 2002). The depression was observed at all atmospheric levels, and there was also a zone of high pressure that was located to the northwest of the Peninsula with a pressure higher than $1035 \mathrm{hPa}$ that contributed to the strong wind and pressure gradients. The deep low continued its trajectory to the NE and affected Catalonia, giving rise to a windstorm with a recorded maximum wind speed of $170 \mathrm{~km} \mathrm{~h}^{-1}$ (Port-Bou, Area 1). In contrast to the previously described type 1 situation, this event was characterized by very high $H_{\mathrm{s}}$ values along the entire coast (Table 3), exceeding the threshold for severe storms according the Mendoza et al. (2011) storm classification in nearly all areas (except Area 5) and for extreme storms in the northernmost areas (1 and 2.a). Thus, compounding conditions were wave-dominated, with the rainfall being moderate (although exceeding the $40 \mathrm{~mm}$ threshold for P24h) except in the northernmost Area 1, where the P24h was higher than $100 \mathrm{~mm}$. In addition, snowfall in the northern part of the region and severe weather (a tornado in Montgat, Area 3, and hailstorms in Tarragona N and S, Areas 5 and 6, respectively) were also observed. Although many civil protection interventions due to floods and wind action occurred mostly in the central part of the study area, most of the incurred damage was due to coastal (wave)-storm-induced hazards. Thus, the entire coastal zone was severely affected from south to north as the storm propagated along the coast (Fig. 13). In the southernmost part (Area 7), the Ebro Delta plain was extensively flooded, while the beaches were severely eroded. This resulted in significant damage to rice fields and existing infrastructure. Along the entire coast, many ports and marinas were significantly overtopped, with the breakwater of the port of Barcelona being damaged. In some stretches, such as Barcelona (Area 4.a) and some parts of Maresme (Area 3), many beaches were fully eroded, with their promenades being directly exposed to wave action; the coastal railway along Maresme was also impacted. In the northernmost part of the study site (Areas 1 and 2.a), coastal flooding occurred in several municipalities due to massive overtopping of beaches and promenades. In summary, although this was a compound event, the most important and relevant damages were caused by coastal (wave)-storm-induced hazards (Fig. 12).

On 26 and 27 December 2008 (type 3, Fig. 12), a very intense coastal storm affected the Catalan coast and was accompanied by strong winds, snow, and rain. The surface synoptic situation by 26 December was characterized by a pronounced anticyclone in northern Europe extending from Ireland to Russia, centred in Denmark, and a low-pressure area with two clear centres over Catalonia and Valencia and another located over the Azores. Along the Catalan coast, there was strong wet advection from the south-east due to the strong low-high dipole. This situation caused a very high pressure gradient that produced strong advection from the east and south-east of Catalonia. As a result, very high waves and rainfall were recorded along the study area, with the highest values being reached in the northern half of the coast (Areas 1, 2.a, 3, and 4.a). In addition to tangible damage, four fatalities occurred during the episode, three of which were associated with wave action and the fourth occurring from a flood in the Muga River (Area 1 and Table 3). Extreme wave impacts along the coastline induced significant damage, with extensive sediment losses in the beaches, promenades overtopped, and damage to infrastructure (Fig. 13). This occurred especially in the northern part of the coast (Areas 1 and 2.a), where waves reached values typical of extreme storms according to the Mendoza et al. (2011) classification. This was one of the most important recorded coastal storms, with observed impacts also on nearshore ecosystems (e.g. SánchezVidal et al., 2012). On land, the strong wind uprooted a large number of trees and cut off the electricity and telephone lines. The Fabra Observatory in the city of Barcelona recorded a maximum wind gust of approximately $85 \mathrm{~km} \mathrm{~h}^{-1}$. During the event, notable snowfall at low altitudes, some landslides, and a tornado in Platja d'Aro (Area 2.a) occurred. Many roads and train lines were cut off due to heavy snowfall and flooding of the tracks near the sea. The Ministry of the Environ- 


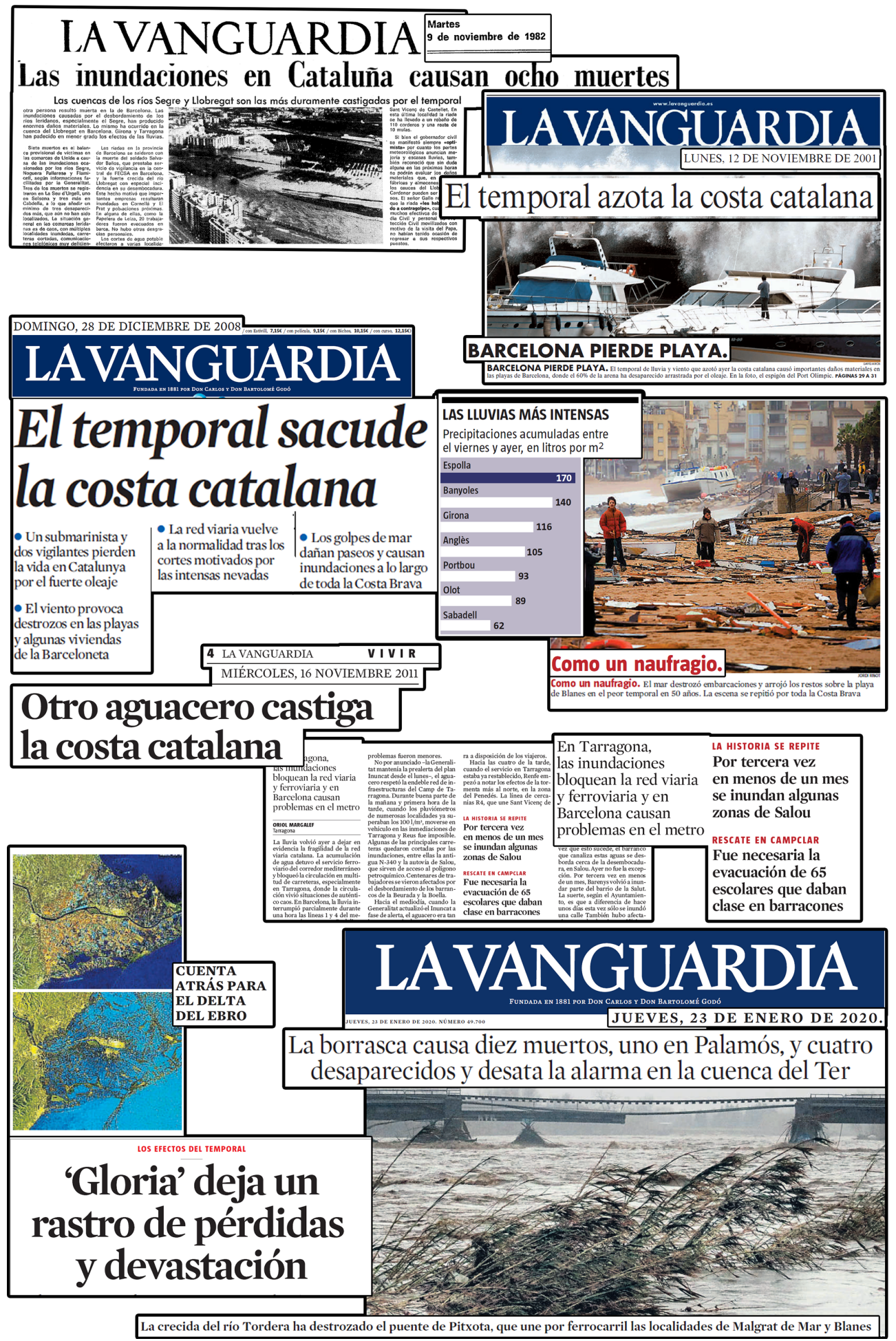

Figure 13. Headlines in a local newspaper (La Vanguardia) after the impact of selected events (Figs. 11 and 12). From top left to bottom right: (9 November 1982) "Eight dead caused by floods in Catalonia"; "Segre and Llobregat basins, the most affected by the event". (12 November 2001) "The storm hits the Catalan coast"; "Barcelona loses its beaches". (28 December 2008) "The storm shakes the Catalan coast"; "The most intense rains"; "Like a wreck". (16 November 2011) "The downpour punishes the Catalan coast"; "Flooding disrupts train and underground networks in Tarragona and Barcelona"; "Floods in Salou for the third time in a month"; "65 children evacuated from poorly built schools". (23 January 2020) "Gloria leaves a pathway of destruction and losses"; "The storm causes 10 dead (one in Palamós), four missing and all alarms triggered at the Ter basin"; "Final countdown at the Ebro Delta". 
ment allocated an equivalent of EUR 21.6 million (adjusted for 2020) to different municipalities on the Catalan coast to carry out emergency work, with the aim of repairing the damage caused by the waves on beaches and coastal infrastructure. The government granted aid packages to several municipalities and fisherfolk of more than EUR 0.72 million (adjusted for 2020).

Recently, the severe storm Gloria took place in the Catalan Sea in January 2020 (Fig. 12), with record-breaking events occurring in all areas for both wave heights and rainfall (Table 3). It started as a small superficial depression (about $600 \mathrm{~km}$ in diameter) located in the central part of the North Atlantic Ocean, which was increasing while moving eastward. By 18 January, the storm had nearly doubled in size, while the Azores High was being reinforced further south. On 19 and 20 January, the high-pressure zone moved to the north of the Gloria storm, leaving the latter over the south of the Iberian Peninsula. Between 20 and 23 January, both areas were well defined in the form of a dipole creating a strong pressure gradient that gave rise to very intense winds while favouring the entry of maritime air over the study area (Berdalet et al., 2020). The synoptic pattern (on 20 January +00:00 UTC, closest to the coastal storm start time) corresponded to a type 3 synoptic event. Wave heights recorded during the peak of the storm along the Catalan coast reached record maximum values, and they were accompanied by the presence of a moderate storm surge, reaching values of $\sim 0.5 \mathrm{~m}$ in the southernmost area (Amores et al., 2020; Jiménez, 2020). Wave impacts produced significant erosion at the beaches, with massive overtopping and flooding of low-lying areas such as the Ebro delta, waterfronts, and marinas as well as structural damage in some coastal groins and port breakwaters (Jiménez, 2020). The extreme coastal storm was accompanied by very intense rainfall and thunderstorms throughout the territory, reaching record values from the last seven decades, which significantly contributed to flooding along some coastal plains, occasional cut-offs and damage to roads and railways. The Department of Interior of the Government of Catalonia responsible for civil protection services activated three emergency plans for risk management: INUNCAT (flash floods, river floods, and coastal floods), NEUCAT (snowfalls, significant above $600 \mathrm{~m}$ ), and VENTCAT (wind, extreme gusts lasting about $48 \mathrm{~h}$, with a maximum of $144 \mathrm{~km} \mathrm{~h}^{-1}$ ). These hazards caused four casualties (and 10 more in the Balearic Islands and Valencia) and extensive damage throughout the territory (Fig. 13), with a preliminary evaluation of payments to be covered by the Spanish public re-insurance company (CCS) rising up to about EUR 51 million. Inversions to rebuild port infrastructures affected by the storm are estimated to be about EUR 17.4 million; about EUR 6 million was budgeted by MITECO to repair damage in the public coastal domain, and damage due to floods in the river margins and flood plains was estimated at EUR 42 million by the Catalan Water Agency (ACA).
Notably, in agreement with the obtained results, both type 2 and 3 events (Fig. 12) are more severe than type 1 in terms of coastal storms. Heavy rainfall produced local floods and dangerous discharges in ephemeral rivers during both type 2 and type 3 events. Nonetheless, type 3 events are potentially the most compounding and intense, with Gloria 2020 being a perfect example of possible extreme impacts (e.g. Canals and Miranda, 2020; ICGC, 2020).

\section{Discussion}

This study can be classified as an exploratory analysis prior to a classical probabilistic approach. While being simple, it allowed us to identify the occurrence, main characteristics, and spatial distribution of main types of compound events along the Catalan coastal zone at the NW Mediterranean. Due to specific conditions of the area, rainfall and waves are the drivers considered to compose the analysed events. The former is a proxy for runoff that results in flash floods, and the latter is a proxy for run-up, which is dominant over storm surge, while providing information on the magnitude of erosion processes.

The approach adopted to classify spatially compound events allows for the identification of the dominant type of driver and, therefore, the dominant type of induced risks that will clearly condition risk management strategies. Moreover, in order to perform a sound bivariate probabilistic analysis of spatially compound events, it is necessary to define the spatial domain to be considered. In this sense, this preliminary exploratory analysis identifies the "connected" coastal sectors and the dominant extreme contribution. Once identified, a more formal probabilistic analysis can be performed to calculate the probability of occurrence of a given type of event in a given part of the territory.

This analysis has served to characterize the current scenario of these compound events in the NW Mediterranean on a timescale of about 40 years (1973 to 2013), which can be used as the reference state for future studies on the impacts of climate change. Obtained results show a spatial focus of most frequent co-occurrence and highest severity in the northernmost coast, as well as the absence of any statistically significant temporal trend in occurrence. With respect to future projections of individual drivers, Tramblay and Somot (2018) report an increase in heavy rainfall in the northern Mediterranean basin, while Llasat et al. (2016) report a possible increase in convective rainfall, resulting in more flash floods in the region. On the other hand, existing wave projections for the area do not show any statistically significant change in storminess (e.g. Casas-Prat and Sierra-Pedrico, 2013). In spite of this, future evolution of compound events will not necessarily be a linear combination of individual projections. At present, the existing information on the influence of climate change on compound events in the area is limited to the analysis done by Bevacqua et al. (2019) at European scale, al- 
though they used storm surge as the marine component. The severity of induced damages, and the large spatial variation detected in their characteristics at a regional scale, makes it necessary to evaluate possible changes in their temporal and spatial occurrence, as well as in their intensity.

To implement the adopted methodological approach, a series of different choices were made that may condition the results obtained, which are discussed as follows. The basic spatial unit has been selected in terms of hydrological basins incorporating all streams reaching the coastal zone in a given area, which in our case were already defined by the Catalan Water Agency for hydrological management. The selection of automatic weather stations (AWSs) was made to ensure good spatial and temporal coverage within basins along the coast during the study period (1973-2013). Although we have not performed a formal sensitivity analysis, the spatial coverage should ensure that significant heavy rainfall events will not be excluded, even in spatially localized episodes (in the case their scale is of the same order of magnitude of AWS local coverage). However, the total number of AWSs within a given basin could affect the maximum $\mathrm{P} 24 \mathrm{~h}$ value recorded for each event, as this value may spatially vary. Accordingly, although a change in the number of AWS could slightly affect the number of compound events when they are close to selected threshold conditions ( $\mathrm{P} 24 \mathrm{~h} \sim 40 \mathrm{~mm}$ ), and/or the rainfall peak value reached in a given basin, it is not expected to have a significant impact on the results obtained for assessment purposes.

In this work, we have used a $3 \mathrm{~d}$ window to define compound events for consistency with the definition of coastal storms in the study area. This is the time interval between consecutive storms to consider them statistically independent and generated by different meteorological conditions (e.g. Mendoza et al., 2011; Sanuy et al., 2020). When the time lag between consecutive storms is shorter than this value, they are considered multiple-peak events, which are not infrequent in the area and play an important role in controlling storm-induced coastal risk (see e.g. Sanuy and Jiménez, 2021). Thus, heavy rainfall and wave storms occurring within this time window are part of the same event. Moreover, this time window is also meaningful for risk management purposes, when in the presence of a SC-compound event, civil protection services may be overwhelmed when responding to cumulative impacts in spatially distant locations in the territory in such a short time interval. This value depends on the characteristics of the study site, and the use of a different time window may be recommended in other areas depending on local (natural or management) conditions.

To characterize synoptic weather conditions responsible for analysed compound events, we have used data from NCEP/NCAR reanalysis. Although the relatively coarse resolution of this dataset will not allow us to properly characterize mesoscale convective features, it is enough to represent the general synoptic conditions (e.g. Beck et al., 2016), and it has been used to investigate the relationship of differ- ent climate-related variables, such as precipitation extremes, floods, river runoff, and fires, with weather types in the NW Mediterranean basin (see, for example, Merino et al., 2016; Gilabert and Llasat, 2018; Duane and Brotons, 2018; PeñaAngulo et al., 2019). Although weather types have been classified using $1000 \mathrm{hPa}$ geopotential, the convenience of incorporating upper air through information has been reported when the final purpose is to predict rainfall (e.g. El Kenawy et al., 2014; Pook et al., 2014).

In this work we have identified synoptic types using a correlation-based map classification, which is an intuitive and simple way of automating the same task performed by an analyst (Yarnal, 1993; Yarnal et al., 2001). It produces good separation between weather types, i.e. a good degree of similarity between cases within the same cluster and dissimilarity between clusters (Huth et al., 2008). One of its main limitations is that it is not as consistent as other approaches such as $\mathrm{K}$-mean clustering or principal component analysis (PCA), since it is generally sensitive to the choice of parameters to be set a priori (such as the cut-off threshold). This is also related to the fact the method tends to produce a large class followed by smaller ones (snowball effect). However, these limitations were minimized by performing a two-step interclass comparison, i.e. a first classification with low thresholds $(\mathrm{rt}=0.2)$ and a second classification using the preliminary classes obtained in the first one and maximizing the correlation coefficient (rt), leading to final classes with two large groups ( $\sim 40 \%$ of cases $)$ and a follow-up one $(\sim 20 \%$ of cases). In any case, alternative weather typing could be implemented (e.g. Huth et al., 2008; Philipp et al., 2010; Dayan et al., 2012).

One of the important criteria applied to define the events was the spatial scale of the compounding effect. For the case of multivariate events, when both drivers must co-occur at the same site, the spatial dimension is here determined by the extent of the watersheds that collect rainfall discharging in a given area of the coastal zone. Other works, especially when dealing with large-scale analysis, such as Wahl et al. (2015) and Ward et al. (2018), establish the spatial link in terms of a maximum distance between rainfall and marine stations. While this is practical for identifying possible connected points at a very large scale, it is not necessarily physically correct. In the case of spatially compounding events, the scale is here defined in terms of risk management. In this sense, the maximum dimension of the area to compound the individual events is taken as the administrative region where the risks/damages should be managed by a given civil protection agency. This selection is based on the very reason underlying the definition of SC events, i.e. the potential overwhelming of the capacity of emergency-response services. Otherwise, it is very likely that if the spatial scale is extended, the probability of a spatially compound event will increase, although its individual induced impacts should not be managed together. In this context, the overall spatial scale of this study has been set to Catalonia, since the Catalan Gov- 
ernment has the responsibility of managing civil protection services in this autonomous region. Otherwise, from a climatological and physical standpoint, the area of analysis of potential spatially connected events should be expanded to comprise the entire NW Mediterranean basin, where extreme precipitation events and coastal storms often impact more than one "national" area (e.g. Lionello et al., 2006; Llasat et al., 2010; Raveh-Rubin and Wernli, 2015).

When analysing the importance of the different types of compound events along this part of the NW Mediterranean, on average, about $35 \%$ of the events take place as multivariate, with the northernmost area being the area having the highest co-occurrence of up to $50 \%$ of the events. This implies that, although they may be locally relevant, SC events are the most demanding in terms of risk management services. The most "extended" component across the territory during a compound event is the marine one, especially in the central part (areas 3 to 6) (Fig. 6), where, on average, $67 \%$ of the events present high waves. The exception to this is found in the northernmost areas 1 and 2, where the rainfall component is slightly predominant, and in the southernmost zone, where both components are equally frequent. These areas at the limits of the territory are also where the most intense components are found. Despite the spatial dominance of the marine component, the magnitude of damages across the territory is clearly dominated by extreme rainfall. The reason must be found in the scale of action of both components. Coastal storms impact on a fringe partially protected by beaches, with promenades and other linear infrastructures receiving most of the impact, in such a way that the extension of the hinterland to be affected is, in general, small, and, in consequence, damages are limited to exposed values at these areas together with the cost of recovery of beaches (e.g. Jiménez et al., 2011, 2012, 2018; Ballesteros et al., 2018a, b; Sanuy and Jiménez, 2021). On the other hand, the occurrence of extreme rainfall in large areas within the catchment basin distributes the impact in a normally highly urbanized territory, as is the case of the Mediterranean coastal area, causing very large damages (e.g. Llasat et al., 2010, 2013; Barredo et al., 2012). This large difference between the magnitude of the impact of both components also conditions the main target of protection services that devote most of the efforts to manage rainfall/flood risks due to their greater severity.

\section{Conclusions}

From the obtained results, the north-western Mediterranean coast represented by the Catalan littoral zone can be characterized as an area with a relatively high probability of experiencing compound extreme events ( 3.4 events $\mathrm{yr}^{-1}$ ) as defined in terms of heavy rainfall (P24h) and wave storms $\left(H_{\mathrm{S}}\right)$. The most frequently found type along the territory is the spatially compound event, which is mostly dominated by waves, whereas the influence of intense rainfall has a smaller spatial scale. However, even for the relatively small scale of the area (about $600 \mathrm{~km}$ of coastline), there is a significant variation in event characteristics along the territory, which may have important implications for risk management. Thus, the two northernmost sectors (Girona N and Lower Ter-Tordera) are the most likely to suffer from multivariate compound events, in such a way that they are the only geographical areas in which their frequency of occurrence exceeds the other type. These areas also present the highest correlation in the intensity of both hazards ( $\mathrm{P} 24 \mathrm{~h}$ and $H_{\mathrm{s}}$ ). The other area in which multivariate events exceed the average frequency along the territory (although with a frequency smaller than spatially compound events) is the southernmost area (the lower Ebro and delta, Area 7).

This pattern is verified under all synoptic situations, although with some particularities that are related to dominant weather conditions at the start of the compounding coastal storm. Thus, events generated under type 1 conditions are dominated more by extreme rainfall because wave storms do not usually reach significantly high values, especially along the central part of the coast. In contrast, compound events generated under types 2 and 3 are more likely to be characterized by the presence of extreme coastal storms, especially in the north, where they might also be accompanied by extreme rainfall $(\mathrm{P} 24 \mathrm{~h}>100 \mathrm{~mm})$. Type 2 events occur half as frequently as types 1 and 3 and are mainly associated with the occurrence of extreme waves $\left(H_{\mathrm{s}}>5.5 \mathrm{~m}\right)$ at the northern and southern ends of the region. Under these synoptic situations, labelled as Mediterranean cyclones, the most extreme coastal storms have been recorded on the Catalan coast (Mendoza et al., 2011). Nonetheless, type 3 events can be as severe as type 2 events in terms of waves, with higher probabilities of compounding simultaneous extreme rainfall.

Compound event characteristics under each dominant weather type in terms of the spatial distribution and intensity were characterized using a BN. With the exception of the two northernmost basins where multivariate events are dominant, the dominant typology is the spatially compound event (wave-dominated). This means that the extension of the affected area is usually larger for waves than for flash floods. In spite of this, the damage associated with heavy rainfall is usually much larger than that due to wave action.

The selected historical compound events are good examples of their potential consequences in an economically developed NW Mediterranean coastal zone. Even at a relatively small regional scale, they have an uneven spatial distribution in terms of the dominant typology, hazard severity (rain and waves), and the correlation between them. The dominant synoptic conditions under which these events are generated have been clearly identified, with each inducing different types of events.

Code availability. To retrieve weather data from the NCEP/NCAR Reanalysis datasets, the RNCEP library of R- 
Cran (https://doi.org/10.1111/j.2041-210X.2011.00138.x; Kemp et al., 2012) was used. MATLAB scripts were used to automatize the different steps of the analysis and are not publicly available.

Data availability. Wave data were obtained from IH-Cantabria and rain data were obtained from AEMET. They are not publicly available (see references in the text).

Author contributions. JAJ and MCL conceived the study. MS prepared the methodological framework and analysed the data, with all authors discussing results and implications. MS and TR were responsible for data preprocessing and curation. MS and JAJ prepared the manuscript with contributions of all authors. JAJ and MCL were responsible for funding acquisition and supervision.

Competing interests. The authors declare that they have no conflict of interest.

Disclaimer. Publisher's note: Copernicus Publications remains neutral with regard to jurisdictional claims in published maps and institutional affiliations.

Special issue statement. This article is part of the special issue "Understanding compound weather and climate events and related impacts (BG/ESD/HESS/NHESS inter-journal SI)". It is not associated with a conference.

Acknowledgements. This work has been done in the framework of the M-CostAdapt (CTM2017-83655-C2-1\&2-R) research project, funded by the Spanish Ministry of Economy and Competitiveness (MINECO/AEI/FEDER, UE). The authors express their gratitude to IH-Cantabria and Puertos del Estado for supplying wave data, and AEMET and SMC for supplying rain data. Our thanks are given to Montserrat Llasat-Botija for her contribution in the identification of the compound events as well as for all the information about the impacts.

Financial support. This research has been supported by the Ministerio de Economía y Competitividad (grant no. CTM2017-83655C2-1\&2-R).

Review statement. This paper was edited by Carlo De Michele and reviewed by Jakob Zscheischler and two anonymous referees.

\section{References}

Alfieri, L., Burek, P., Feyen, L., and Forzieri, G.: Global warming increases the frequency of river floods in Europe, Hydrol. Earth
Syst. Sci., 19, 2247-2260, https://doi.org/10.5194/hess-19-22472015, 2015.

Amores, A., Marcos, M., Carrió, D. S., and Gómez-Pujol, L.: Coastal impacts of Storm Gloria (January 2020) over the northwestern Mediterranean, Nat. Hazards Earth Syst. Sci., 20, 19551968, https://doi.org/10.5194/nhess-20-1955-2020, 2020.

Ballesteros, C., Jiménez, J. A., and Viavattene, C.: A multi-component flood risk assessment in the Maresme coast (NW Mediterranean), Nat. Hazards, 90, 265-292, https://doi.org/10.1007/s11069-017-3042-9, 2018a.

Ballesteros, C., Jiménez, J. A., Valdemoro, H. I., and Bosom, E.: Erosion consequences on beach functions along the Maresme coast (NW Mediterranean, Spain), Nat. Hazards, 90, 173-195, https://doi.org/10.1007/s11069-017-3038-5, 2018b.

Barbería, L., Amaro, J., Aran, M., and Llasat, M. C.: The role of different factors related to social impact of heavy rain events: considerations about the intensity thresholds in densely populated areas, Nat. Hazards Earth Syst. Sci., 14, 1843-1852, https://doi.org/10.5194/nhess-14-1843-2014, 2014.

Barnolas, M. and Llasat, M. C.: A flood geodatabase and its climatological applications: the case of Catalonia for the last century, Nat. Hazards Earth Syst. Sci., 7, 271-281, https://doi.org/10.5194/nhess-7-271-2007, 2007.

Barredo, J. I., Saurí, D., and Llasat, M. C.: Assessing trends in insured losses from floods in Spain 1971-2008, Nat. Hazards Earth Syst. Sci., 12, 1723-1729, https://doi.org/10.5194/nhess12-1723-2012, 2012.

Beck, C., Philipp, A., and Streicher, F.: The effect of domain size on the relationship between circulation type classifications and surface climate, Int. J. Climatol., 36, 2692-2709, https://doi.org/10.1002/joc.3688, 2016.

Berdalet, E., Marrasé, C., and Pelegrí, J. L.: La Borrasca Gloria 19-24 enero 2020, Institut de Ciències del Mar, CSIC, 38 pp. https://doi.org/10.20350/digitalCSIC/12496, 2020.

Berghuijs, W. R., Harrigan, S., Molnar, P., Slater, L. J., and Kirchner, J. W.: The relative importance of different flood-generating mechanisms across Europe, Water Resour. Res., 55, 4582-4593, https://doi.org/10.1029/2019WR024841, 2019.

Beuzen, T., Splinter, K. D., Marshall, L. A., Turner, I. L., Harley, M. D., and Palmsten, M. L.: Bayesian Networks in coastal engineering: Distinguishing descriptive and predictive applications, Coast. Eng., 135, 16-30, https://doi.org/10.1016/j.coastaleng.2018.01.005, 2018.

Bevacqua, E., Maraun, D., Vousdoukas, M. I., Voukouvalas, E., Vrac, M., Mentaschi, L., and Widmann, M.: Higher probability of compound flooding from precipitation and storm surge in Europe under anthropogenic climate change, Science Advances, 5, eaaw5531, https://doi.org/10.1126/sciadv.aaw5531, 2019.

Blöschl, G., Kiss, A., Viglione, A., Barriendos, M., Böhm, O., Brázdil, R., Coeur, D., Demarée, G., Llasat, M.C., Macdonald, N., Retsö, D., Roald, L., Schmocker-Fackel, P., Amorim, I., Bělínová, M., Benito, G., Bertolin, C., Camuffo, D., Cornel, D., Doktor, R., Elleder, L., Enzi, S., Garcia, J. C., Glaser, R., Hall, J., Haslinger, K., Hofstätter, M., Komma, J., Limanówka, D., Lun, D., Panin, A., Parajka, J., Petrić, H., Rodrigo, F. S., Rohr, C., Schönbein, J., Schulte, L., Silva, L. P., Toonen, W. H. J., Valent, P., Waser, J., and Wetter, O.: Current European flood-rich period exceptional compared with past 500 years, Nature, 583 , 560-566, https://doi.org/10.1038/s41586-020-2478-3, 2020. 
Bolaños, R., Jordá, G., Cateura, J., Lopez, J., Puigdefabregas, J., Gómez, J., and Espino, M.: The XIOM: 20 years of a regional coastal observatory in the Spanish Catalan coast, J. Marine Syst., 77, 237-260, https://doi.org/10.1016/j.jmarsys.2007.12.018, 2009.

Bosom, E. and Jiménez, J. A.: Probabilistic coastal vulnerability assessment to storms at regional scale - application to Catalan beaches (NW Mediterranean), Nat. Hazards Earth Syst. Sci., 11, 475-484, https://doi.org/10.5194/nhess-11-475-2011, 2011.

Camus, P., Mendez, F. J., Medina, R., Tomas, A., and Izaguirre, C.: High resolution downscaled ocean waves (DOW) reanalysis in coastal areas, Coast. Eng., 72, 56-68, https://doi.org/10.1016/j.coastaleng.2012.09.002, 2013.

Canals, M. and Miranda, J. (Eds.): Sobre el temporal Gloria (19.-23.01.20), els seus efectes sobre el país i el que se'n deriva, Report de Resposta Ràpida (R3), Institut d'Estudis Catalans, Col-lecció Informes, Informe de la Secció de Ciències i Tecnologia, Barcelona, Spain, 196 pp., available at: https://www.iec.cat/activitats/documents/IEC_R3_Temporal_ Gloria_2020.pdf (last access: June 2021), 2020.

Casas-Prat, M. and Sierra, J. P.: Trend analysis of wave storminess: wave direction and its impact on harbour agitation, Nat. Hazards Earth Syst. Sci., 10, 2327-2340, https://doi.org/10.5194/nhess10-2327-2010, 2010.

Casas-Prat, M., and Sierra-Pedrico, J. P.: Projected future wave climate in the NW Mediterranean Sea, J. Geophys. Res.-Oceans, 118, 3548-3568, https://doi.org/10.1002/jgrc.20233, 2013.

Cortès, M., Turco, M., Llasat-Botija, M., and Llasat, M. C.: The relationship between precipitation and insurance data for floods in a Mediterranean region (northeast Spain), Nat. Hazards Earth Syst. Sci., 18, 857-868, https://doi.org/10.5194/nhess-18-8572018, 2018.

Cramer, W., Guiot, J., Fader, M., Garrabou, J., Gattuso, J.-P., Iglesias, A., Lange, M. A., Lionello, P., Llasat, M. C., Paz, S., Peñuelas, J., Snoussi, M., Toreti, A., Tsimplis, M. N., and Xoplaki, E.: Climate change and interconnected risks to sustainable development in the Mediterranean, Nat. Clim. Chang., 8, 972-980, https://doi.org/10.1038/s41558-018-0299-2, 2018.

Dayan, U., Tubi, A., and Levy, I.: On the importance of synoptic classification methods with respect to environmental phenomena, Int. J. Climatol., 32, 681-694, https://doi.org/10.1002/joc.2297, 2012.

Duane, A. and Brotons, L.: Synoptic weather conditions and changing fire regimes in a Mediterranean environment, Agr. Forest Meteorol., 253, 190-202, https://doi.org/10.1016/j.agrformet.2018.02.014, 2018.

El Kenawy, A. M., McCabe, M. F., Stenchikov, G. L., and Raj, J.: Multi-decadal classification of synoptic weather types, observed trends and links to rainfall characteristics over Saudi Arabia, Frontiers in Environmental Science, 2, 37, https://doi.org/10.3389/fenvs.2014.00037, 2014.

Fita, Ll., Romero, R., and Ramis, C.: Intercomparison of intense cyclogenesis events over the Mediterranean basin based on baroclinic and diabatic influences, Adv. Geosci., 7, 333-342, https://doi.org/10.5194/adgeo-7-333-2006, 2006.

Garnier, E., Ciavola, P., Spencer, T., Ferreira, O., Armaroli, C., and McIvor, A.: Historical analysis of storm events: case studies in France, England, Portugal and Italy, Coast. Eng., 134, 10-23, https://doi.org/10.1016/j.coastaleng.2017.06.014, 2018.
Gaume, E., Borga, M., Llasat, M. C., Maouche, S., Lang, M., and Diakakis, M.: Mediterranean extreme floods and flash floods, in: The Mediterranean Region under Climate Change. A Scientific Update, IRD Editions, Marseille, Coll Synthèses, 978-2-70992219-7, pp. 133-144, 2016.

Genest, C. and Favre, A-C.: Everything you always wanted to know about copula modeling but were afraid to ask, J. Hydrol. Eng., 12, 347-368, https://doi.org/10.1061/(ASCE)10840699(2007)12:4(347), 2007.

Genovés, A. and Jansà, A.: Diabatic processes contribution to the november 2001 storm, Mediterranean Storms, Proceedings of the 4th EGS Plinius Conference, 2-4 October 2002, Mallorca, Spain, 2002.

Gilabert, J. and Llasat, M. C.: Circulation weather types associated with extreme flood events in Northwestern Mediterranean, Int. J. Climatol., 38, 1864-1876, https://doi.org/10.1002/joc.5301, 2018.

Gutierrez, B. T., Plant, N. G., and Thieler, E. R.: A Bayesian network to predict coastal vulnerability to sea level rise, J. Geophys. Res.-Earth, 116, 1-15, https://doi.org/10.1029/2010JF001891, 2011.

Hall, J., Arheimer, B., Borga, M., Brázdil, R., Claps, P., Kiss, A., Kjeldsen, T. R., Kriaučiūnienè, J., Kundzewicz, Z. W., Lang, M., Llasat, M. C., Macdonald, N., McIntyre, N., Mediero, L., Merz, B., Merz, R., Molnar, P., Montanari, A., Neuhold, C., Parajka, J., Perdigão, R. A. P., Plavcová, L., Rogger, M., Salinas, J. L., Sauquet, E., Schär, C., Szolgay, J., Viglione, A., and Blöschl, G.: Understanding flood regime changes in Europe: a state-of-the-art assessment, Hydrol. Earth Syst. Sci., 18, 27352772, https://doi.org/10.5194/hess-18-2735-2014, 2014.

Hallegatte, S., Green, C., Nicholls, R. J., and Corfee-Morlot, J.: Future flood losses in major coastal cities, Nat. Clim. Change, 3, 802-806, https://doi.org/10.1038/nclimate1979, 2013.

Hao, Z., Singh, V. P., and Hao, F.: Compound extremes in hydroclimatology: a review, Water, 10, 718, https://doi.org/10.3390/w10060718, 2018.

Hendry, A., Haigh, I. D., Nicholls, R. J., Winter, H., Neal, R., Wahl, T., Joly-Laugel, A., and Darby, S. E.: Assessing the characteristics and drivers of compound flooding events around the UK coast, Hydrol. Earth Syst. Sci., 23, 3117-3139, https://doi.org/10.5194/hess-23-3117-2019, 2019.

Huth, R., Beck, C., Philipp, A., Demuzere, M., Ustrnul, Z., Cahynová, M., Kyselý, J., and Tveito, O. E.: Classifications of atmospheric circulation patterns: recent advances and applications, Ann. Ny. Acad. Sci., 1146, 105-152, 2008.

ICGC: El temporal Gloria (19-23/01/2020): Els efectes dels processos geològics sobre el territorio, Generalitat de Catalunya, Barcelona, 121 pp., 2020.

Insua-Costa, D., Miguez-Macho, G., and Llasat, M. C.: Local and remote moisture sources for extreme precipitation: a study of the two catastrophic 1982 western Mediterranean episodes, Hydrol. Earth Syst. Sci., 23, 3885-3900, https://doi.org/10.5194/hess-233885-2019, 2019.

IPCC: Special Report on Managing the Risks of Extreme Events and Disasters to Advance Climate Change Adaptation, edited by: Field, C. B., Barros, V., Stocker, T. F., Qin, D., Dokken, D. J., Ebi, K. L., Mastrandrea, M. D., Mach, K. J., Plattner, G.-K., Allen, S. K., Tignor, M., and Midgley, P. M., Cambridge Univ. 
Press, Cambridge, United Kingdom and New York, NY, USA, 2012.

IPCC: Summary for Policymakers, in: Climate Change 2014: Impacts, Adaptation, and Vulnerability. Part A: Global and Sectoral Aspects. Contribution of Working Group II to the Fifth Assessment Report of the Intergovernmental Panel on Climate Change, edited by: Field, C. B., Barros, V. R., Dokken, D. J., Mach, K. J., Mastrandrea, M. D., Bilir, T. E., Chatterjee, M., Ebi, K. L., Estrada, Y. O., Genova, R. C., Girma, B., Kissel, E. S., Levy, A. N., MacCracken, S., Mastrandrea, P. R., and White, L. L., Cambridge University Press, Cambridge, UK and New York, NY, USA, 1-32, 2014.

Jansa, A., Alpert, P., Arbogast, P., Buzzi, A., Ivancan-Picek, B., Kotroni, V., Llasat, M. C., Ramis, C., Richard, E., Romero, R., and Speranza, A.: MEDEX: a general overview, Nat. Hazards Earth Syst. Sci., 14, 1965-1984, https://doi.org/10.5194/nhess14-1965-2014, 2014.

Jensen, F. V.: An introduction to Bayesian networks, UCL Press, London, UK, 1996.

Jiménez, J. A.: Dinàmica litoral, efectes dels temporals i comportament de les platges, in: Sobre el temporal Gloria (19.-23.01.20), els seus efectes sobre el país i el que se'n deriva. Report de Resposta Ràpida (R3), edited by: Canals, M. and Miranda, J., Institut d'Estudis Catalans, Col-lecció Informes, Informe de la Secció de Ciències i Tecnologia, Barcelona, Spain, p. 55-7, 2020.

Jiménez, J. A. and Valdemoro, H. I.: Shoreline evolution and its management implications in beaches along the Catalan coast, in: The Spanish Coastal Systems Dynamic Processes, Sediments and Management, edited by: Morales, J. A., Springer, Berlin, 745-764, 2019.

Jiménez, J. A., Gracia, V., Valdemoro, H. I., Mendoza, E. T., and Sánchez-Arcilla, A.: Managing erosion-induced problems in NW Mediterranean urban beaches, Ocean Coast. Manag., 54, 907918, https://doi.org/10.1016/j.ocecoaman.2011.05.003, 2011.

Jiménez, J. A., Sancho, A., Bosom, E., Valdemoro, H. I., and Guillén, J.: Storm-induced damages along the Catalan coast (NW Mediterranean) during the period 1958-2008, Geomorphology, 143-144, 24-33, https://doi.org/10.1016/j.geomorph.2011.07.034, 2012.

Kalnay, E., Kanamitsu, M., Kistler, R., Collins, W., Deaven, D., Gandin, L., Iredell, M., Saha, S., White, G., Woollen, J., Zhu, Y., Chelliah, M., Ebisuzaki, W., Higgins, W., Janowiak, J., Mo, K. C., Ropelewski, C., Wang, J., Leetmaa, A., Reynolds, R., Jenne, R., and Joseph, D.: The NCEP/NCAR 40-year reanalysis project, B. Am. Meteorol. Soc., 77, 437-470, https://doi.org/10.1175/15200477(1996)077<0437:TNYRP>2.0.CO;2, 1996.

Kanamitsu, M., Ebisuzaki, W., Woollen, J., Yang, S., Hnilo, J. J., Fiorino, M., and Potter, G. L.: NCEP-DOE AMIPII Reanalysis (R-2), B. Am. Meteorol. Soc., 83, 1631-1643, https://doi.org/10.1175/BAMS-83-11-1631, 2002.

Kemp, M. U., Emiel van Loon, E., Shamoun-Baranes, J., and Bouten, W.: RNCEP: global weather and climate data at your fingertips, Methods Ecol. Evol., 3, 65-70., https://doi.org/10.1111/j.2041-210X.2011.00138.x, 2012.

Kron, W.: Coasts: the high-risk areas of the world, Nat. Hazards, 66, 1363-1382, https://doi.org/10.1007/s11069-012-0215-4, 2013.

Lionello, P., Bhend, J., Buzzi, A., Della-Marta, P. M., Krichak, S. O., Jansà, A., Maheras, P., Sanna, A., Trigo, I. F., and Trigo R.:
Cyclones in the Mediterranean region: climatology and effects on the environment, in: Developments in earth and environmental sciences, Vol. 4, edited by: Lionello, P., Malanotte-Rizzoli, P., and Boscolo, R., Elsevier, https://doi.org/10.1016/S15719197(06)80009-1, 325-372, 2006.

Llasat, M. C.: Episodios de lluvias copiosas en Cataluña: génesis, evolución y factores coadyudantes, $\mathrm{PhD}$ thesis, University of Barcelona, 1987.

Llasat, M. C. and Puigcerver, M.: Pluies extremes en Catalogne: influence orographique et caractéristiques synoptiques, Hydrologie Continentale, 2, 99-115, 1992.

Llasat, M. C., Llasat-Botija, M., and López, L.: A press database on natural risks and its application in the study of floods in Northeastern Spain, Nat. Hazards Earth Syst. Sci., 9, 2049-2061, https://doi.org/10.5194/nhess-9-2049-2009, 2009.

Llasat, M. C., Llasat-Botija, M., Prat, M. A., Porcú, F., Price, C., Mugnai, A., Lagouvardos, K., Kotroni, V., Katsanos, D., Michaelides, S., Yair, Y., Savvidou, K., and Nicolaides, K.: High-impact floods and flash floods in Mediterranean countries: the FLASH preliminary database, Adv. Geosci., 23, 47-55, https://doi.org/10.5194/adgeo-23-47-2010, 2010.

Llasat, M. C., Llasat-Botija, M., Petrucci, O., Pasqua, A. A., Rosselló, J., Vinet, F., and Boissier, L.: Towards a database on societal impact of Mediterranean floods within the framework of the HYMEX project, Nat. Hazards Earth Syst. Sci., 13, 13371350, https://doi.org/10.5194/nhess-13-1337-2013, 2013.

Llasat, M. C., Caumont, O., Flores, I., Garrote, L., Gilabert, J., Llasat-Botija, M., Marcos, R., Nuissier, O., Richard, E., and Rigo, T.: The 6 November 2011 flood event in Catalonia analysis using the DRIHM infrastructure, Proceedings of the Mediterranean Meeting on "Monitoring, modelling and early warning of a extreme events triggered by heavy rainfalls", MEDFRIEND project University of Calabria, Cosenza, Italy, 2628 June, 2014a.

Llasat, M. C., Marcos, R., Llasat-Botija, M., Gilabert, J., Turco, M., and Quintana, P.: Flash flood evolution in North-Western Mediterranean, Atmos. Res., 149, 230-243, https://doi.org/10.1016/j.atmosres.2014.05.024, 2014b.

Llasat, M. C., Marcos, R., Turco, M., Gilabert, J., and Llasat-Botija, M.: Trends in flash flood events versus convective precipitation in the Mediterranean region: the case of Catalonia, J. Hydrol., 541, 24-37, https://doi.org/10.1016/j.jhydrol.2016.05.040, 2016.

Mendoza, E. T. and Jiménez, J. A.: Regional vulnerability analysis of Catalan beaches to storms, P. I. Civil. Eng.-Mar. En., 162, 127135, https://doi.org/10.1680/maen.2009.162.3.127, 2009.

Mendoza, E. T., Jimenez, J. A., and Mateo, J.: A coastal storms intensity scale for the Catalan sea (NW Mediterranean), Nat. Hazards Earth Syst. Sci., 11, 2453-2462, https://doi.org/10.5194/nhess-11-2453-2011, 2011.

Merino, A., Fernández-Vaquero, M., López, L., FernándezGonzález, S., Hermida, L., Sánchez, J. L., García-Ortega, E., and Gascón, E.: Large-scale patterns of daily precipitation extremes on the Iberian Peninsula, Int. J. Climatol., 36, 3873-3891, https://doi.org/10.1002/joc.4601, 2016.

Michaelides, S., Karacostas, T., Sánchez, J. L., Retalis, A., Pytharoulis, I., Homar, V., Romero, R., Zanis, P., Giannakopoulos, C., Bühl, J., Ansmann, A., Merino, A., Melcón, P., Lagouvardos, K., Kotroni, V., Bruggeman, A., López-Moreno, J. I., Berthet, C., Katragkou, E., Tymvios, F., Hadjimitsis, D. G., 
Mamouri, R.-E., and Nisantzi, A.: Reviews and perspectives of high impact atmospheric process in the Mediterranean, Atmos. Res., 208, 4-44, https://doi.org/10.1016/j.atmosres.2017.11.022, 2018.

Moftakhari, H. R., Salvadori, G., AghaKouchak, A., Sanders, B. F. and Matthew, R. A.: Compounding effects of sea level rise and fluvial flooding, P. Natl. Acad. Sci. USA, 114, 9785-9790, https://doi.org/10.1073/pnas.1620325114, 2017.

Paprotny, D., Vousdoukas, M. I., Morales-Nápoles, O., Jonkman, S. N., and Feyen, L.: Pan-European hydrodynamic models and their ability to identify compound floods, Nat. Hazards, 101, 933-957, https://doi.org/10.1007/s11069-020-03902-3, 2020.

Pearl, J.: Probabilistic reasoning in intelligent systems: networks of plausible inference, Morgan Kaufmann, San Francisco, California, USA, 1988.

Peña-Angulo, D., Nadal-Romero, E., González-Hidalgo, J. C., Albaladejo, J., Andreu, V., Bagarello, V., Barhi, H., Batalla, R. J., Bernal, S., Bienes, R., Campo, J., Campo-Bescós, M. A., Canatario-Duarte, A., Cantón, Y., Casali, J., Castillo, V., Cerdà, A., Cheggour, A., Cid, P., Cortesi, N., Desir, G., DíazPereira, E., Espigares, T., Estrany, J., Fernández-Raga, M., Ferreira, C. S. S., Ferro, V., Gallart, F., Giménez, R., Gimeno, E., Gómez, J. A., Gómez-Gutiérrez, A., Gómez-Macpherson, H., González-Pelayo, O., Hueso-González, P., Kairis, O., Karatzas, G. P., Klotz, S., Kosmas, C., Lana-Renault, N., Lasanta, T., Latron, J., Lázaro, R., Le Bissonnais, Y., Le Bouteiller, C., Licciardello, F., López-Tarazón, J. A., Lucía, A., Marín, C., Marqués, M. J., Martínez-Fernández, J., Martínez-Mena, M., Martínez-Murillo, J. F., Mateos, L., Mathys, N., MerinoMartín, L., Moreno-de las Heras, M., Moustakas, N., Nicolau, J. M., Novara, A., Pampalone, V., Raclot, D., RodríguezBlanco, M. L., Rodrigo-Comino, J., Romero-Díaz, A., Roose, E., Rubio, J. L., Ruiz-Sinoga, J.D., Schnabel, S., SencialesGonzález, J. M., Simonneaux, V., Solé-Benet, A., Taguas, E. V., Taboada-Castro, M. M., Taboada-Castro, M. T., Todisco, F., Úbeda, X., Varouchakis, E. A., Vericat, D., Wittenberg, L., Zabaleta, A., and Zorn, M.: Spatial variability of the relationships of runoff and sediment yield with weather types throughout the Mediterranean basin, J. Hydrol., 571, 390-405, https://doi.org/10.1016/j.jhydrol.2019.01.059, 2019.

Philipp, A., Bartholy, J., Beck, C., Erpicum, M., Esteban, P., Fettweis, X., Huth, R., James, P., Jourdain, S., Kreienkamp, F., Krennert, T., Lykoudis, S., Michalides, S. C., PiankoKluczynska, K., Post, P., Álvarez, D. R., Schiemann, R., Spekat, A., and Tymvios, F. S.: Cost733cat - A database of weather and circulation type classifications, Phys. Chem. Earth Pts. A/B/C, 35, 360-373, https://doi.org/10.1016/j.pce.2009.12.010, 2010.

Plant, N. G., Thieler, R. E., and Passeri, D. L.: Coupling centennialscale shoreline change to sea-level rise and coastal morphology in the Gulf of Mexico using a Bayesian network, Earths Future, 4, 143-158, https://doi.org/10.1002/2015EF000331, 2016.

Pook, M. J., Risbey, J. S., Ummenhofer, C. C., Briggs, P. R., and Cohen, T. J.: A synoptic climatology of heavy rain events in the Lake Eyre and Lake Frome catchments, Frontiers in Environmental Science, 2, 54, https://doi.org/10.3389/fenvs.2014.00054, 2014.

Puigdefàbregas, C.: Efectes geomorfològics dels aiguats del novembre de 1982, Publicacions del Servei Geològic de Catalunya, Departament de Política Territorial i Obres Públiques, 236 pp. 1983.
Ramis, C., Homar, V., Amengual, A., Romero, R., and Alonso, S.: Daily precipitation records over mainland Spain and the Balearic Islands, Nat. Hazards Earth Syst. Sci., 13, 2483-2491, https://doi.org/10.5194/nhess-13-2483-2013, 2013.

Raveh-Rubin, S. and Wernli, H.: Large-scale wind and precipitation extremes in the Mediterranean: a climatological analysis for 1979-2012, Q. J. Roy. Meteor. Soc., 141, 2404-2417, https://doi.org/10.1002/qj.2531, 2015.

Raymond, C., Horton, R. M., Zscheischler, J., Martius, O., AghaKouchak, A., Balch, J., Bowen, S. G., Camargo, S. J., Hess, J., Kornhuber, K., Oppenheimer, M., Ruane, A. C., Wahl, T., and White, K.: Understanding and managing connected extreme events, Nat. Clim. Change, 10, 611-621, https://doi.org/10.1038/s41558-020-0790-4, 2020.

Reguero, B. G., Menéndez, M., Méndez, F. J., Mínguez, R., and Losada, I. J.: A Global Ocean wave (GOW) calibrated reanalysis from 1948 onwards, Coast. Eng., 65, 38-55, https://doi.org/10.1016/j.coastaleng.2012.03.003, 2012.

Sanchez-Vidal, A., Canals, M., Calafat, A. M., Lastras, G., PedrosaPàmies, R., Menéndez, M., Medina, R., Hereu, B., Romero, J., and Alcoverro, T.: Impacts on the deep-sea ecosystem by a severe coastal storm, PLoS one, 7, e30395, 2012.

Sanuy, M. and Jiménez, J. A.: Probabilistic characterisation of coastal storm-induced risks using Bayesian networks, Nat. Hazards Earth Syst. Sci., 21, 219-238, https://doi.org/10.5194/nhess21-219-2021, 2021

Sanuy, M., Jiménez, J. A., Ortego, M. I., and Toimil, A.: Differences in assigning probabilities to coastal inundation hazard estimators: Event versus response approaches, J. Flood Risk Manag., e12557, https://doi.org/10.1111/jfr3.12557, 2020.

Tramblay, Y. and Somot, S.: Future evolution of extreme precipitation in the Mediterranean, Climatic Change, 151, 289-302, 2018.

Trapero, L., Bech, J., Duffourg, F., Esteban, P., and Lorente, J.: Mesoscale numerical analysis of the historical November 1982 heavy precipitation event over Andorra (Eastern Pyrenees), Nat. Hazards Earth Syst. Sci., 13, 2969-2990, https://doi.org/10.5194/nhess-13-2969-2013, 2013.

Van Dongeren, A., Ciavola, P., Martinez, G., Viavattene, C., Bogaard, T., Ferreira, O., Higgins, R., and McCall, R.: Introduction to RISC-KIT: Resilienceincreasing strategies for coasts, Coast. Eng., 134, 2-9, https://doi.org/10.1016/j.coastaleng.2017.10.007, 2018.

Vinet, F., Bigot, V., Petrucci, O., Papagiannaki, K., Llasat, M. C., Kotroni, V., Boissier, L., Aceto, L., Grimalt, M., Llasat-Botija, M., Pasqua, A. A., Rossello, J., Kılıç, Ö., Kahraman, A., and Tramblay, Y.: Mapping Flood-Related Mortality in the Mediterranean Basin, Results from the MEFF v2.0 DB, Water, 11, 2196, https://doi.org/10.3390/w11102196, 2019.

Wahl, T., Jain, S., Bender, J., Meyers, S. D., and Luther, M. E.: Increasing risk of compound flooding from storm surge and rainfall for major US cities, Nat. Clim. Change, 5, 1093-1097, https://doi.org/10.1038/nclimate2736, 2015.

Ward, P. J., Couasnon, A., Eilander, D., Haigh, I. D., Hendry, A., Muis, S., Veldkamp, T. I., Winsemius, H. C. and Wahl, T.: Dependence between high sea-level and high river discharge increases flood hazard in global deltas and estuaries, Environ. Res. Lett., 13, 084012, https://doi.org/10.1088/17489326/aad400, 2018 
Wu, W., McInnes, K., O’Grady, J., Hoeke, R., Leonard, M. and Westra, S.: Mapping dependence between extreme rainfall and storm surge, J. Geophys. Res.-Oceans, 123, 2461-2474, https://doi.org/10.1002/2017JC013472, 2018.

Yarnal, B.: Synoptic climatology in environmental analysis, Belhaven Press, London, UK, 1993.

Yarnal, B., Comrie, A. C., Frakes, B., and Brown, D. P.: Developments and prospects in synoptic climatology, Int. J. Climatol., 21, 1923-1950, 2001.
Zscheischler, J., Martius, O., Westra, S., Bevacqua, E., Raymond, C., Horton, R. M., van den Hurk, B., AghaKouchak, A., Jézéquel, A., Mahecha, M. D., Maraun, D., Ramos, A. M., Ridder, N. N., Thiery, W., and Vignotto, E.: A typology of compound weather and climate events, Nature Reviews Earth \& Environment, 1, 333-347, https://doi.org/10.1038/s43017-020-0060-z, 2020. 